Research Article

\title{
Research on the Deformation and Control Technology of Surrounding Rock in Entry Retaining along the Gob Side
}

\author{
Meng Zhang, ${ }^{1}$ Hui He, ${ }^{1}$ Yu Zhang, ${ }^{1,2}$ Xin Jin, ${ }^{1}$ Xinyu Liang, ${ }^{1}$ Yidong Zhang $\left(\mathbb{D},{ }^{3}\right.$ \\ and Hongjun Guo ${ }^{4}$ \\ ${ }^{1}$ School of Civil \& Architecture Engineering, Xi'an Technological University, Xi'an 710021, China \\ ${ }^{2}$ Shaanxi Key Laboratory of Loess Mechanics and Engineering, Xi'an University of Technology, Xi'an 710048, China \\ ${ }^{3}$ State Key Laboratory of Coal Resources and Mine Safety, China University of Mining \& Technology, Xuzhou 221116, China \\ ${ }^{4}$ Jiangsu Vocational Institute of Architectural Technology, Xuzhou 221116, China
}

Correspondence should be addressed to Yidong Zhang; ydzhang@cumt.edu.cn

Received 24 June 2020; Revised 31 July 2020; Accepted 28 August 2020; Published 16 September 2020

Academic Editor: Bisheng Wu

Copyright ( $\odot 2020$ Meng Zhang et al. This is an open access article distributed under the Creative Commons Attribution License, which permits unrestricted use, distribution, and reproduction in any medium, provided the original work is properly cited.

\begin{abstract}
This paper studies and introduces the successful case of gob-side entry retaining technology and the typical mining pressure law in Luan mining area, which is the main mining coal seam in Qinshui coalfield. Qinshui coalfield has an estimated coal reserve of 300 billion tons, accounting for $9.58 \%$ of the total national coal reserve in China, especially anthracite, chemical coal, and coking coal. The methods of field investigation, theoretical analysis, physical experiment, and industrial test are adopted. Through the field investigation, theoretical analysis, physical experiments, and industrial test, the following conclusions have been drawn in this study: (1) A thorough engineering geological investigation was conducted on the entry retaining along the gob side on noncoal pillar mining working face, which covers multiple periods of mining process including the roadway excavation period, primary mining period, primary mining stability period, and secondary mining influence period. A series of analysis and tests were conducted such as core sampling, rock mechanics property testing, borehole detection, and flexible formwork support evaluation, which laid a foundation for identifying the mining pressure law of gob-side entry retaining by using noncoal pillar mining. (2) The mining pressure law was studied through the collection of the field measurements taken from the entry retaining along the gob side on noncoal pillar mining working face. The keys to achieve the roadway surrounding rock stability through noncoal pillar mining are obtained. According to the study, the stability control of retained roadway surrounding rock mainly depends on the stability of top coal, coal side, and shoulder angle coal. (3) In this study, a roadway reinforcement scheme is proposed to improve the surrounding rock control technology for gob-side entry retaining by noncoal pillar mining, whose effectiveness has been verified by a series of industrial test. Therefore, the wide adoption of the noncoal pillar mining method in Number \#3 coal mine can significantly relieve the predicament of coal pressing under a large number of buildings in Luan mining area, which provides insightful guidance to the coal-free pillar mining in the whole Luan mining area.
\end{abstract}

\section{Introduction}

Entry retaining along the gob side refers to that in order to recover the protective coal pillars reserved in the traditional mining method, the roadway in the upper section is resupported by certain technical means and left to the next section for use. This is of practical significance to the technical transformation of production mine, relaxation of mining relationship, and extension of mine life. Luan mining area contains a total of 10 planned mines and 8 production mines, namely, Shigejie mine, Wuyang mine, Zhangcun mine, Changcun mine, Wangzhuang mine, Tunliu mine, Sima mine, and Gaohe mine. No 3\# coal seam is the main mining area. Locating in the eastern part of Qinshui coalfield, the mining area is about $44-77 \mathrm{~km}$ long from north to south and $63.1 \mathrm{~km}$ wide from east to west. The total area of the mining area is about $2052.8 \mathrm{~km}^{2}$. Ordovician limestone is the basement of the coal measures in the mining area, and the coal-bearing strata are mainly Carboniferous and Permian strata, with Shanxi Formation of the Lower 
Permian and Taiyuan Formation of the Upper Carboniferous as the main bodies. No $3 \#$ coal seam locates in the middle and lower parts of Shanxi Formation as the main mineable coal seam in this area. In addition, Nos. 6, 9, 14, and 15-2\# coal seams are only partially minable. Under the event that no pillar is utilized in the mining process of No.3 coal, a higher coal recovery rate can be achieved by eliminating the pillar and additional constructions [1-3]. Therefore, the study of the mining pressure law of $3 \#$ coal seam mining can provide insightful guidance to the coal-free pillar mining in the whole Luan mining area. During the study, a typical mine called Gaohe was selected as the main study subject [4-6].

\section{Engineering Overview}

2.1. Engineering Geological Overview of E1316 Intake Entry. The current production capacity of Gaohe mine is $8.0 \mathrm{mt} / \mathrm{a}$, which belongs to high-yield and high-efficiency mine. E1316 intake entry is surrounded by the E1316 working face at the south side, the goaf of E1315 working face on the north side, and five main roadways on the west side, which serve as the auxiliary transportation roadway of the south wing at $+450 \mathrm{~m}$ level. The E1316 intake entry is located in the $3 \#$ coal seam with a total length of $1087 \mathrm{~m}$ and drivage along the roadway floor. The specific roadway location is shown in Figure 1. Gaohe mine is a typical high-gas mine. The absolute gas emission volume of the mine is as high as $253.92 \mathrm{~m}^{3} / \mathrm{min}$. Considering that it has the high gas content and emission, the ventilation mode of E1316 working face was changed from the "Y-type + High pumping roadway" ventilation mode to the "W-type + High pumping roadway" ventilation mode to optimize the ventilation system and recover coal resources as much as possible. In addition, the noncoal pillar mining was implemented.

No. $3^{\#}$ coal seam in the E1316 working face is deposited in the Shanxi Formation of the Permian as lagoon facies. The working face locates in a syncline structural area with a stable coal seam thickness ranging from $6.2 \mathrm{~m}$ to $7.1 \mathrm{~m}$ and an average coal thickness of $6.5 \mathrm{~m}$. The whole coal is sandwiched with a layer of carbonaceous mudstone, whose thickness ranges from $0.10 \mathrm{~m}$ to $0.35 \mathrm{~m}$ with an average thickness of $0.20 \mathrm{~m}$. The coal seam has a dip angle of $1^{\circ}$ to $7^{\circ}$ and an average inclination of $5^{\circ}$. The depth of coal seam is $430.123 \mathrm{~m}-446.942 \mathrm{~m}$, and the average distance from 9\# coal seam is about $64.7 \mathrm{~m}$. The test results of rock (coal) mechanical properties are summarized in Table 1.

\subsection{Introduction of E1316 Intake Entry Support}

2.2.1. Roadway Support Form. The details of the roadway support section are shown in Figure 2(a) with roadway support parameters shown in Table 2. Due to the production needs, E1316 intake entry was reinforced by the adoption of a shelf structure as shown in Figure 2(a).

2.2.2. Details of the Flexible Formwork Support. The strength of the flexible formwork support in E1316 intake entry was achieved through the application of the C30 concrete to the E1316 intake entry flexible formwork wall. The concrete parameters are provided in Table 3.

\section{Law of Mine Pressure of the Gob-Side Entry Retaining during the First Mining Period}

\subsection{Deformation Law of Surrounding Rock of Gob-Side Entry Retaining}

3.1.1. Pressure Observation Station. The surface displacement of entry is monitored by the cross point method. Before the mining of E1315 working face, the mine pressure observation stations are arranged in the ventilation roadway of E1315 working face with No. 1\# station set at 270 meters away from the cut hole and No. 2\# stationset at 330 meters away from the cut hole. The location of the station and the observation objects are shown in Figure 1 and Table 4, respectively.

3.1.2. Law of Mine Pressure Appearance along the Gob-Side Entry Retaining in Front of E1315 Working Face

(1) Surface Deformation Law of Entry. After processing the deformation observation data obtained from No. $1 \#$ measuring point, an entry deformation curve was developed and is presented in Figure 3.

As demonstrated in Figure 3, the surface deformation of the gob-side entry retaining in front of E1315 working face can be divided into three stages:

(1) No mining influence stage: beyond 72 meters in front of the working face, the entry in this section is basically not affected by the mining. The cumulative deformation of entry roof and floor is limited with the entry maintenance in good condition.

(2) Low mining influence stage: with the advancing of the working face, in the range of $32-72 \mathrm{~m}$ ahead of the working face, the advance abutment pressure of the working face causes the increases of the subsidence rate of the roof, floor, and two sides of the entry gradually. The collected field data suggest that the average moving rate of the two sides is $8.63 \mathrm{~mm} / \mathrm{d}$ with a maximum moving rate of $23 \mathrm{~mm} / \mathrm{d}$. Meanwhile, the average moving rate of the roof and floor is $5.6 \mathrm{~mm} / \mathrm{d}$ with a maximum moving rate of $12 \mathrm{~mm} / \mathrm{d}$. In this stage, the cumulative deformation of the two sides is $138 \mathrm{~mm}$ with a total of $90 \mathrm{~mm}$ cumulative deformation in the roof and floor.

(3) High mining influence stage: as the working face advances, in the range of $0-32 \mathrm{~m}$, the deformation rate of the entry increases dramatically. The average moving rate of the two sides is $18 \mathrm{~mm} / \mathrm{d}$, with a maximum moving rate of $27 \mathrm{~mm} / \mathrm{d}$. Meanwhile, the average moving rate of the roof and floor is $20.7 \mathrm{~mm} / \mathrm{d}$, with a maximum moving rate of $54 \mathrm{~mm} / \mathrm{d}$.

Therefore, advanced supporting systems should be installed within $72 \mathrm{~m}$ of the influence range of entry. 


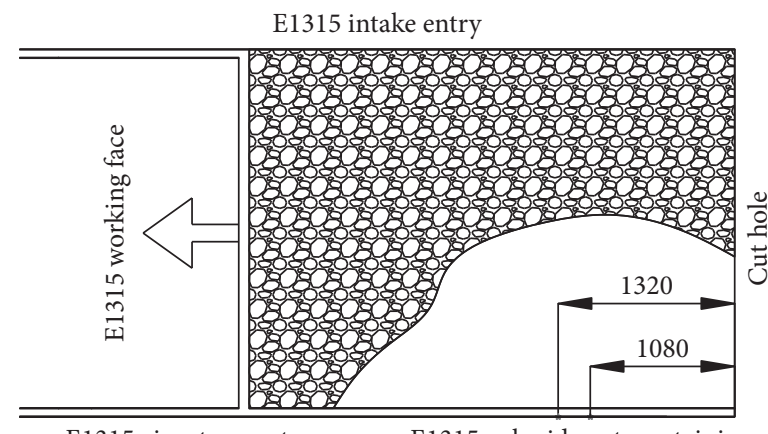

E1315 air return entry

E1315 gob-side entry retaining

Figure 1: The layout of E1316 working face and entry.

TABLE 1: Mechanical parameters of coal.

\begin{tabular}{|c|c|c|c|c|c|c|c|}
\hline Name & Type & $\begin{array}{c}\text { Compressive } \\
\text { strength }(\mathrm{MPa})\end{array}$ & $\begin{array}{c}\text { Tensile } \\
\text { strength }(\mathrm{MPa}) \\
\end{array}$ & $\begin{array}{c}\text { Cohesion } \\
(\mathrm{MPa})\end{array}$ & $\begin{array}{c}\text { Internal friction } \\
\text { angle }(\mathrm{MPa})\end{array}$ & $\begin{array}{c}\text { Modulus of } \\
\text { elasticity }(\mathrm{GPa})\end{array}$ & Poisson's ratio \\
\hline $\begin{array}{l}\text { Main } \\
\text { roof }\end{array}$ & Packsand & 46.63 & 4.96 & 7.76 & 36 & 28.85 & 0.20 \\
\hline $\begin{array}{l}\text { Direct } \\
\text { roof }\end{array}$ & $\begin{array}{l}\text { Sandy } \\
\text { mudstone }\end{array}$ & 23.44 & 3.85 & 4.68 & 33 & 3.69 & 0.27 \\
\hline 3\# coal & 3\# coal & 9.49 & 1.12 & 2.12 & 30 & 1.53 & 0.27 \\
\hline $\begin{array}{l}\text { Direct } \\
\text { floor }\end{array}$ & Siltstone & 28.51 & 3.71 & 5.98 & 35 & 24.49 & 0.17 \\
\hline
\end{tabular}

3.1.3. Law of Mine Pressure Appearance along the Gob-Side Entry Retaining at the Rear of the E1315 Working Face. Figure 4 shows the deformation and deformation rate curve of the $2 \#$ measuring point. The surface deformation of the gob-side entry retaining at the rear of the E1315 working face can be divided into two stages.

No. 2\# measuring station is $330 \mathrm{~m}$ away from the cut hole, locating at 201 meters behind the current working face. The cumulative displacement of the roof and floor reached $1121 \mathrm{~mm}$ with a total of $1070 \mathrm{~mm}$ cumulative displacement at sides. The roof subsidence is the most severe one, followed by the floor subsidence and lateral substance. The deformation of the coal pillar side in advance entry was not as severe as the solid coal side. At the beginning of the mining of the working face, the deformation was observed at the measuring station, which locates at about 10 meters ahead of the working face. Gradually, the roadway deformation speed increased. The roof and floor moved at the maximum rate of $72 \mathrm{~mm} / \mathrm{d}$, with the maximum rate of two sides at $28.5 \mathrm{~mm} / \mathrm{d}$. A "step sinking" on the roof in front of the working face was identified, which led to the rapid increase of deformation rate.

After retaining the entry, the deformation speed of the entry firstly increased significantly and then decreased gradually. When the distance between the measuring station and the back of the working face reached $32 \mathrm{~m}$, the roof and floor moved at a rate of $14 \mathrm{~mm} / \mathrm{d}$ with intensified deformation speed. The roof and floor moved at the maximum rate of $45 \mathrm{~mm} / \mathrm{d}$, with a maximum rate of the two sides at $28.5 \mathrm{~mm} / \mathrm{d}$. When the distance reached $40-60 \mathrm{~m}$ behind the working face, the deformation of the entry became severe and continued for a whole week. It was presumed that the main roof of the working face collapses for the first time.
Meanwhile, the advancing distance of the working face was 80-100 m. The deformation of the retaining entry near the No. 2 measuring station grew stable.

(1) The increasing stage of deformation speed of the working face after mining: within a certain range after the working face was pushed, the immediate roof above the goaf failed and collapsed, accompanied by the main roof failure and rotation sinking. The entry deformation speed reached the maximum [7-10]. Simultaneously the maximum deformation rate of the two sides reached $27.5 \mathrm{~mm} / \mathrm{d}$ and the maximum moving rate of the roof and floor was as high as $42.5 \mathrm{~mm} / \mathrm{d}$ in the radius of $80 \mathrm{~m}$ behind the working face. In this whole stage, the cumulative deformation at both sides of the entry reached $655 \mathrm{~mm}$ with $752 \mathrm{~mm}$ cumulative deformation in the roof and floor.

(2) The decreasing stage of deformation speed of the working face after mining: as the bearing capacity of the filling wall increased, the key blocks at the end of the working face gradually stabilized under the support of the lower falling rock and filling body, resulting in the decreasing deformation speed of the surrounding rock of the entry. Within the range of 80-192 $\mathrm{m}$ behind the working face, the deformation speed of the entry gradually decreased, resulting in a maximum moving rate of $11.7 \mathrm{~mm} / \mathrm{d}$ at two sides and a maximum moving rate of $12 \mathrm{~mm} / \mathrm{d}$ in the roof and floor $[11,12]$. The cumulative deformation at both sides of the entry reached $302 \mathrm{~mm}$, and the cumulative deformation of the roof and floor was as high as $270 \mathrm{~mm}$. 


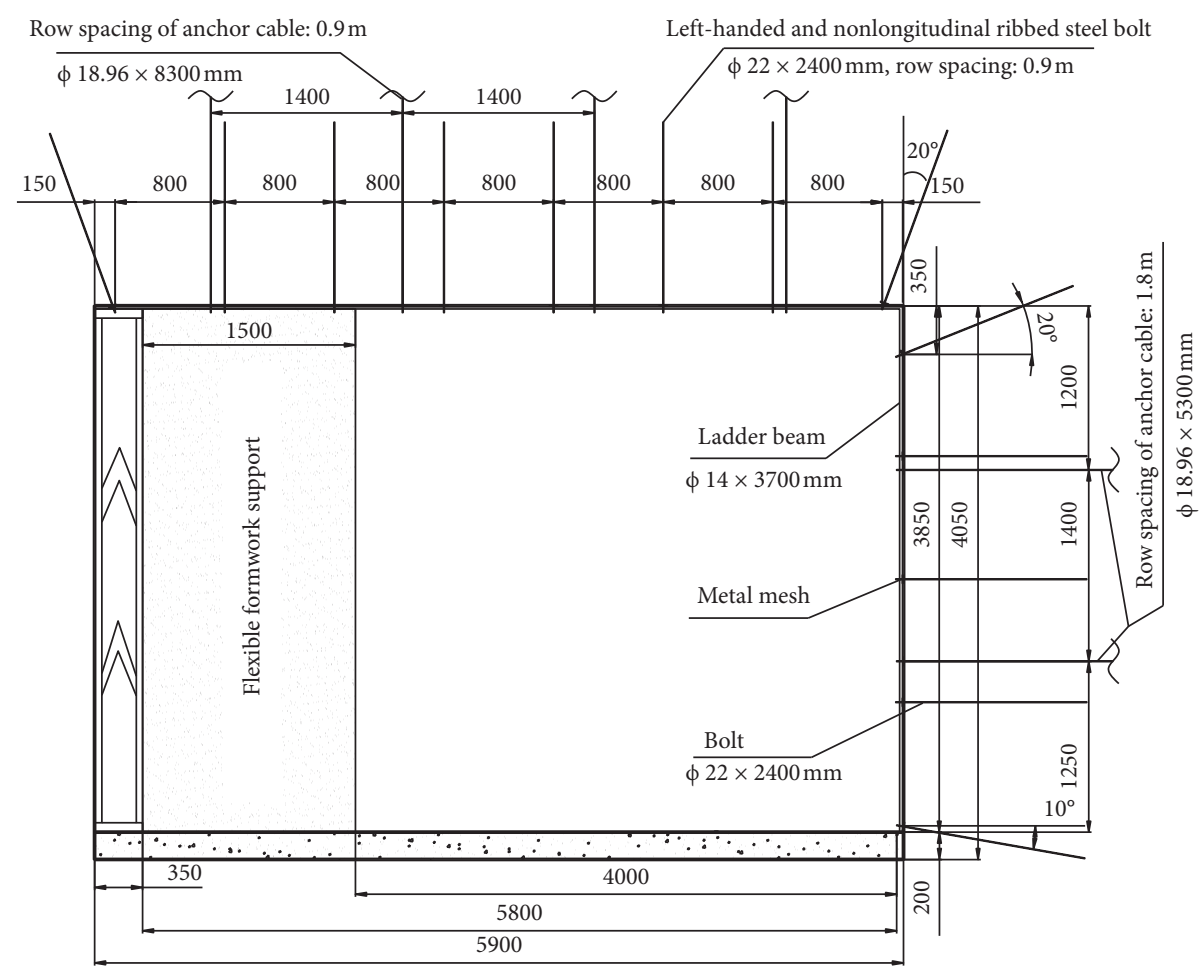

(a)

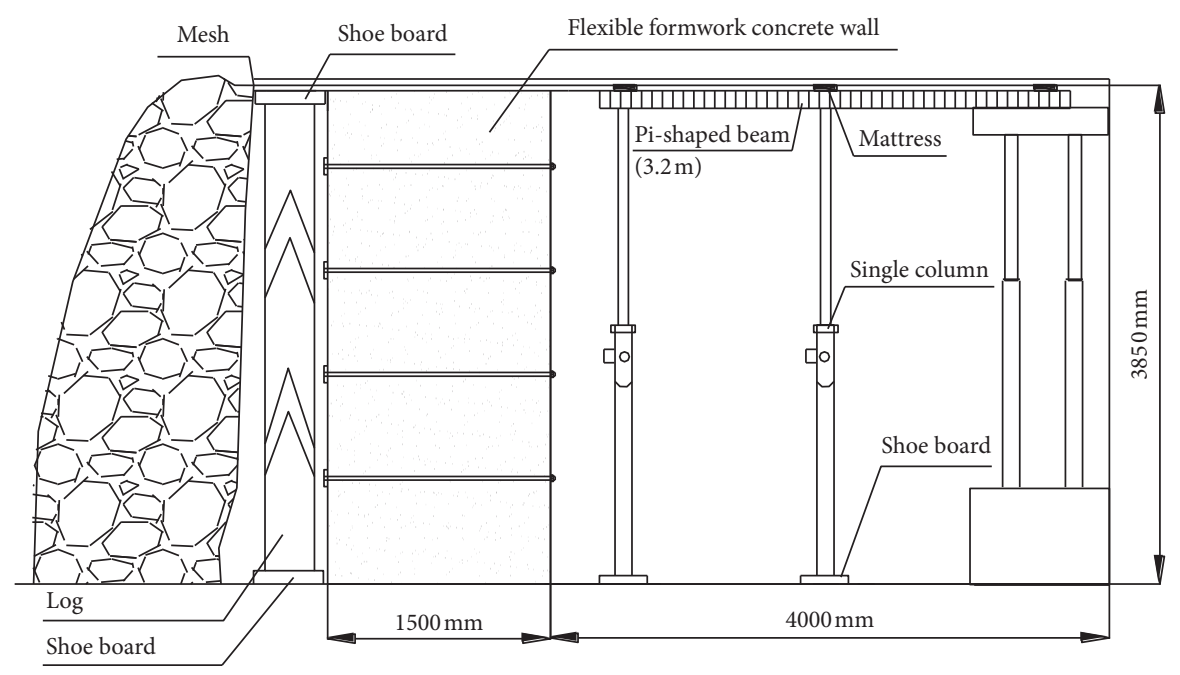

(b)

Figure 2: Roadway support form. (a) The supporting profile of the intake entry. (b) The shelf supporting profile of E1316 intake entry.

(3) The stable stage of deformation speed of the working face after mining: the rotary subsidence of overburden strata on the roof grew stable gradually $190 \mathrm{~m}$ behind the working face. The deformation speed of the surrounding rock followed a similar trend. No visible crack and failure were observed in the filling wall. Despite that, the entry wall was rated as the low stress area, and the plastic zone of the entry surrounding rock had penetrated the coal body. Both sides moved at the maximum rate of $3.5 \mathrm{~mm} / \mathrm{d}$ with the maximum rate of $3 \mathrm{~mm} / \mathrm{d}$ in the roof and floor.
3.2. Supporting Stress in Coal Pillar along the Gob-Side Entry Retaining, the Load Distribution, and the Variation Law of Flexible Formwork Support Body

3.2.1. Pressure Variation of Single Prop. As shown in Figure 5, the pressure of single hydraulic prop in advance support of roadway was monitored. The curves were developed with the collected data and corresponding analysis.

The analysis of the working resistance of single hydraulic prop before mining suggested that the working resistance of the prop continued to increase in the range of $0-35 \mathrm{~m}$ before 
TABLE 2: Roadway support parameters.

\begin{tabular}{|c|c|c|}
\hline \multicolumn{2}{|l|}{ The name of roadway } & E1316 intake entry \\
\hline \multirow{3}{*}{ The gross section } & Digging width $(\mathrm{mm})$ & 5900 \\
\hline & Digging height $(\mathrm{mm})$ & 4050 \\
\hline & Excavating area $\left(\mathrm{m}^{2}\right)$ & 23.90 \\
\hline \multirow{3}{*}{ The net section } & Net width (mm) & 4000 \\
\hline & Net height $(\mathrm{mm})$ & 3850 \\
\hline & Net area $\left(\mathrm{m}^{2}\right)$ & 15.40 \\
\hline \multicolumn{2}{|c|}{ The row and line space between roof bolts $(\mathrm{mm})$} & $800 \times 900$ \\
\hline \multicolumn{2}{|c|}{ The row and line space between floor bolts ( $\mathrm{mm})$} & $900 \times 900$ \\
\hline \multicolumn{2}{|c|}{ Layout of roof anchor cable } & Four or four layouts \\
\hline \multicolumn{2}{|c|}{ The row and line space between anchor cables $(\mathrm{mm})$} & $1400 \times 900$ \\
\hline \multicolumn{2}{|c|}{ Layout of floor anchor cable } & Two or two layout \\
\hline \multicolumn{2}{|c|}{ The row and line space between anchor cables $(\mathrm{mm})$} & $1400 \times 1800$ \\
\hline \multirow{2}{*}{ Layout of ladder beam } & Side (single reinforcement) & $\Phi 14 \times 3700$ \\
\hline & Roof (double reinforcement) & $\Phi 14 \times 5000$ \\
\hline \multirow{2}{*}{ Layout of mesh (mm) } & Side & $4200 \times 950$ \\
\hline & Roof & $5300 \times 950$ \\
\hline
\end{tabular}

TABLE 3: The parameters of pump injected concrete.

\begin{tabular}{|c|c|c|c|c|c|}
\hline Concrete components & Cementitious material & Water & \multicolumn{2}{|c|}{ Aggregate } & Admixture \\
\hline Name of concrete base material & Cement & Water & Stone & Sand & Admixture \\
\hline $1 \mathrm{~m}^{3}$ concrete base material quality & $550 \mathrm{~kg}$ & $220 \mathrm{~kg}$ & $800 \mathrm{~kg}$ & $765 \mathrm{~kg}$ & $1 \mathrm{~kg}$ \\
\hline
\end{tabular}

TABLE 4: Observations of mine pressure.

\begin{tabular}{llr}
\hline NO & Observation contents & Observation instrument \\
\hline $1^{\#}$ & Surface deformation & Self-made wedge \\
$2^{\#}$ & Surface deformation & Self-made wedge \\
\hline
\end{tabular}

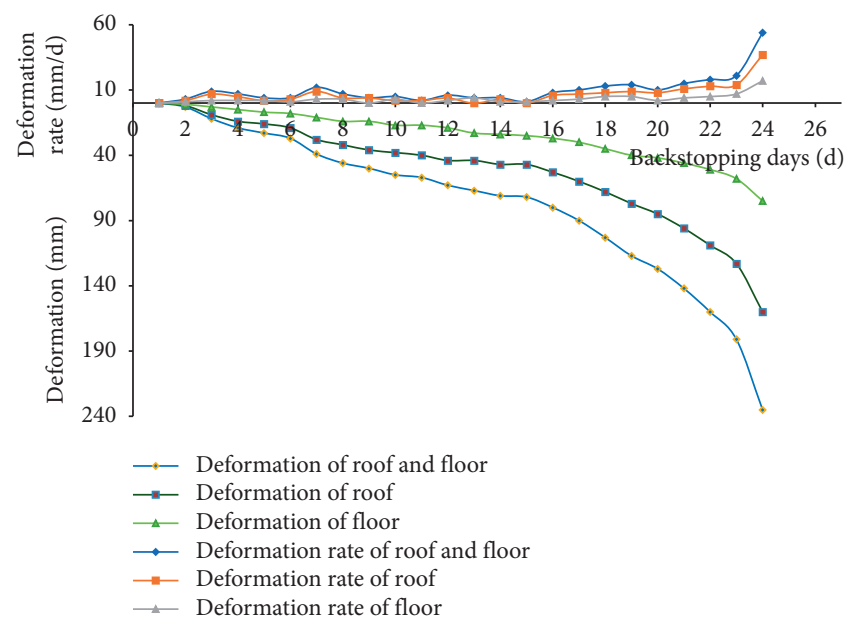

(a)

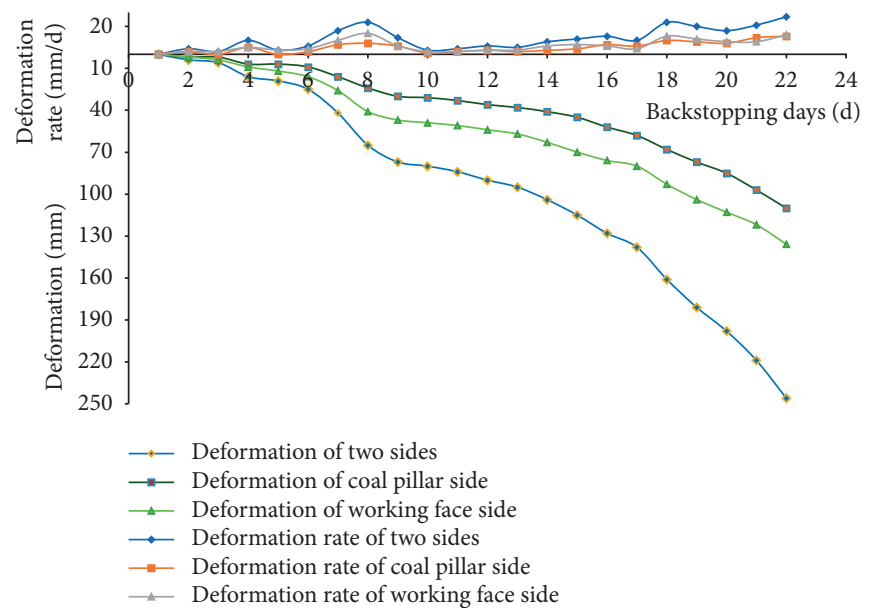

(b)

Figure 3: The entry deformation curve. (a) The deformation rate of roof and floor. (b) The deformation rate of two sides.

the working face. The pressure of the prop at the coal pillar side was the highest, followed by the working face. Due to the advance abutment pressure, the prop pressure continued to rise. After mining, due to the increased distance between the single prop and the working face, the pressure of the single prop experienced increments firstly and decrement at 


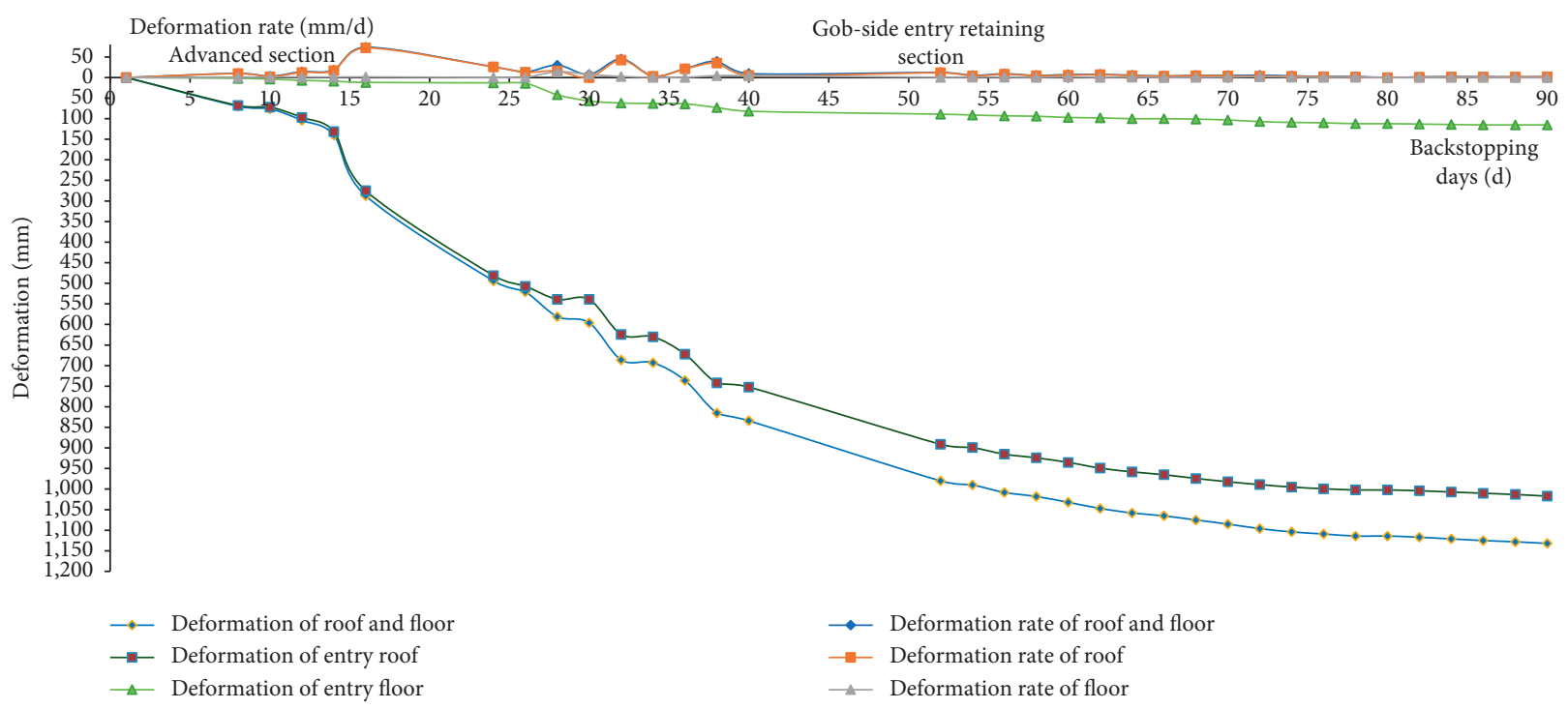

(a)

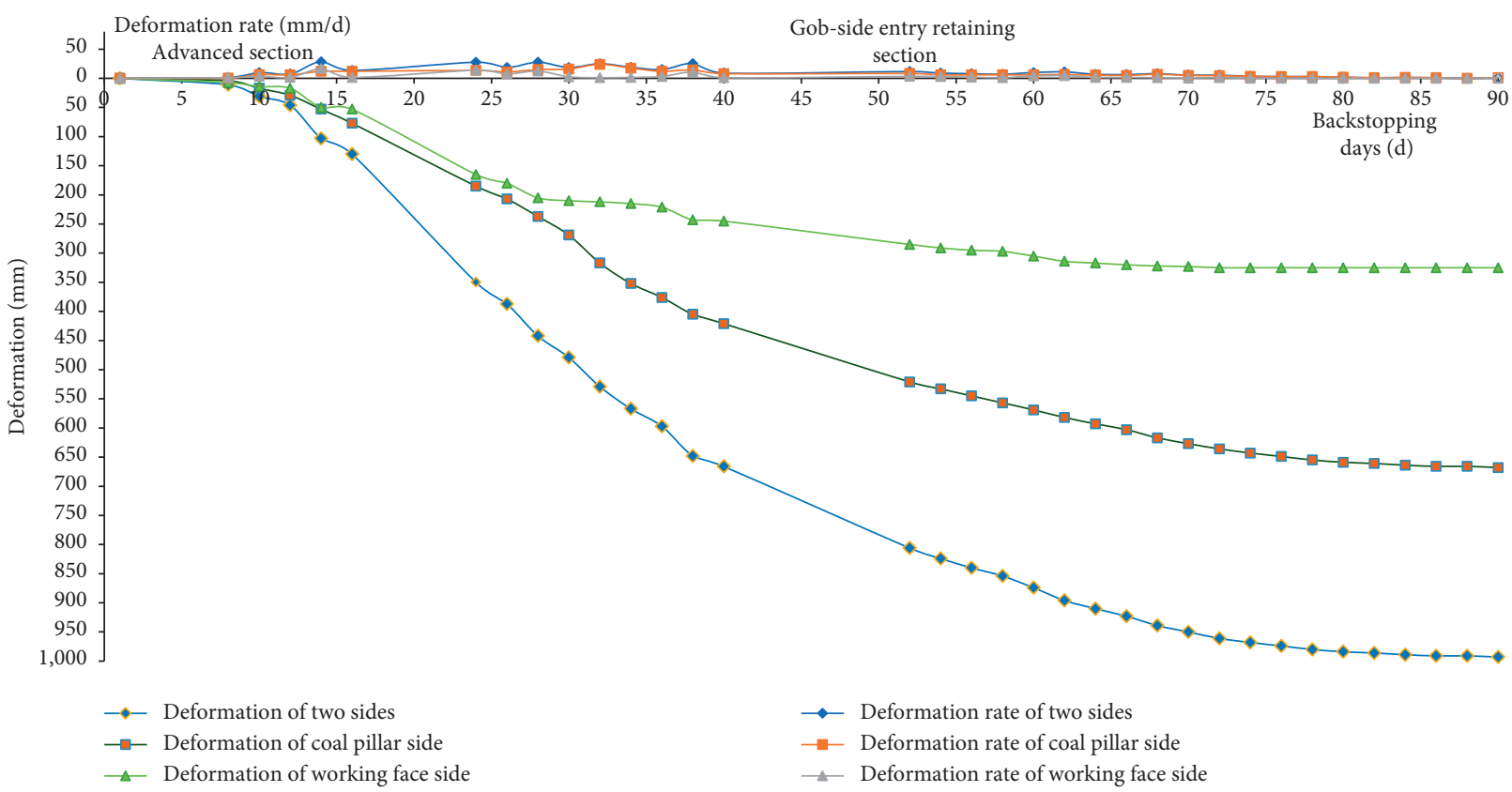

(b)

FIgURE 4: The deformation and deformation rate curve of the 2\# measuring point. (a) I measuring surface. (b) II measuring surface.

30 meters after the working face. Eventually, a stable pressure was reached. After the collapse of the immediate roof, which filled the goaf, the prop pressure firstly decreased and grew stable after the main roof rotation, sinking, and contacting the gangue.

3.2.2. Filling Body Pressure Monitoring. In order to monitor the pressure change of the filling body [13-16], filling body pressure monitoring gauges were installed, respectively, at a distance of $0.3 \mathrm{~m}$ and $0.6 \mathrm{~m}$ from the edge of the filling body, as shown in Figure 6(a). The dimension of the upper load-bearing steel is $30 \times 0.25 \times 0.25 \mathrm{~m}$ (thickness, length, and width, respectively). The dimension of the lower protective steel plate was $0.25 \times 0.3(0.6) \mathrm{m}$, respectively. The pressure gauge observations are shown in Figure 6(b).

As shown in Figure 6, within the range of $0-18.5 \mathrm{~m}$ behind the working face, the pressure on the filling body due to the flexible formwork concrete near roadway increased rapidly, from $141 \mathrm{t}$ at $0.3 \mathrm{~m}$ to $275 \mathrm{t}$ at $0.6 \mathrm{~m}$. Consequently, the filling body pressure gauge failed to monitor at $0.3 \mathrm{~m}$ due to the pipeline damage. With the range of 18.5-32.2 $\mathrm{m}$ behind the working face, the main roof of the stope failed, rotated, and sunk resulting in the increasing pressure of the filling body consistently. According to the pressure gauge reading, the filling body pressure at $27.6 \mathrm{~m}$ behind the working face increased to 


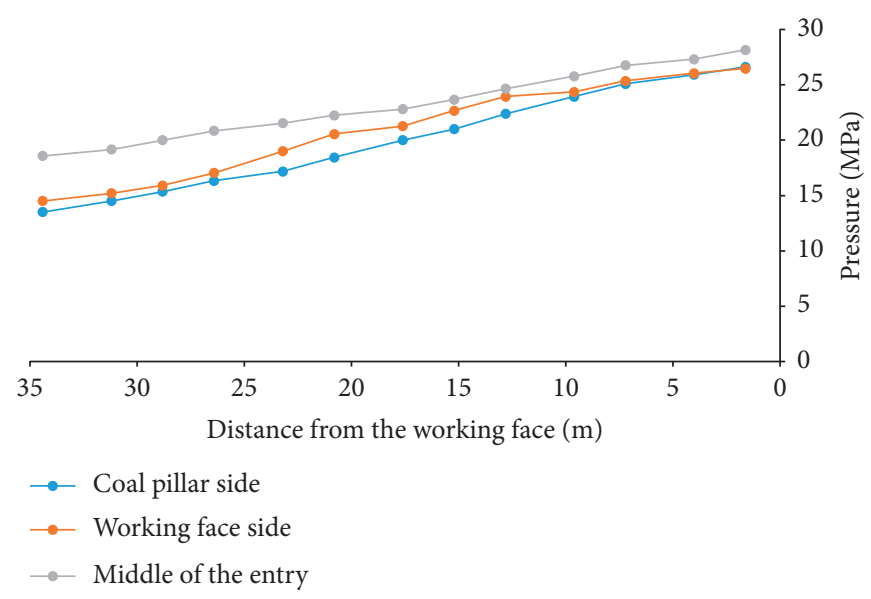

(a)

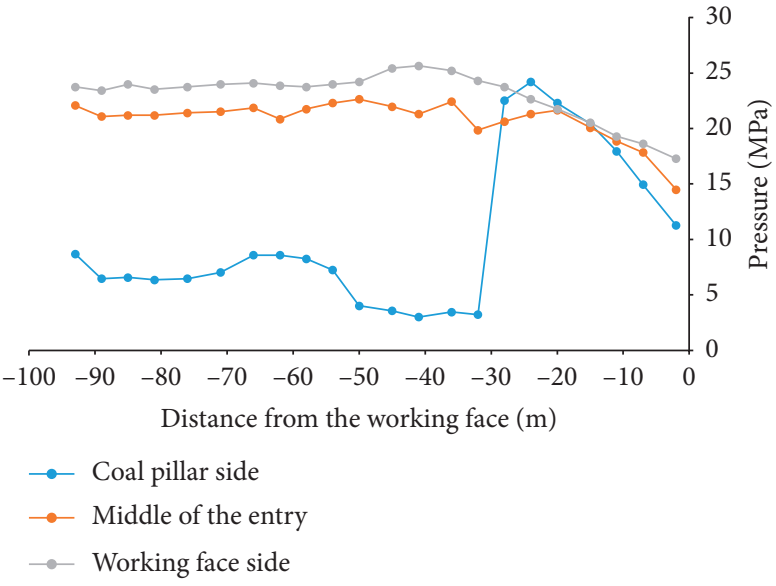

(b)

Figure 5: The pressure change curve of single hydraulic prop in advance support of entry. (a) Before mining. (b) After mining.

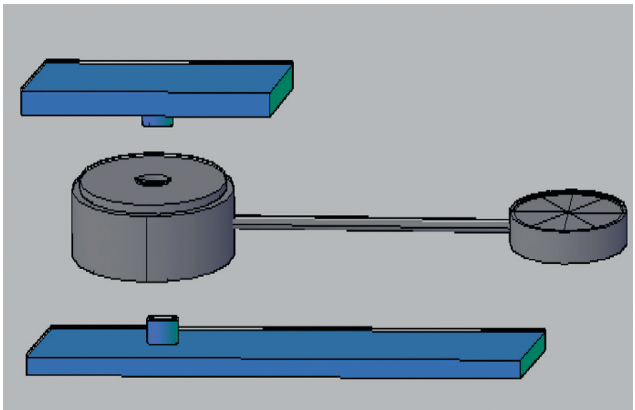

(a)

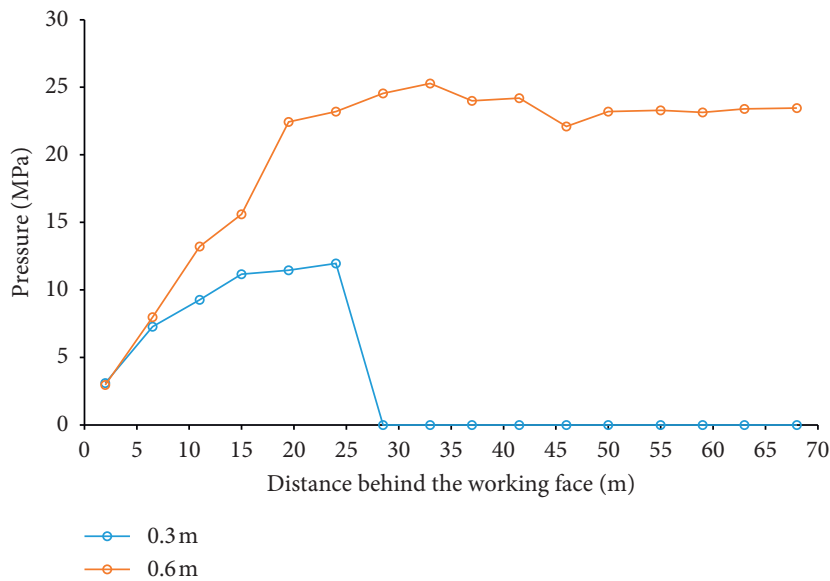

(b)

FIgURE 6: The filling body pressure monitoring. (a) The pressure gauge for the filling body. (b) The pressure gauge reading of the filling body.

$308 \mathrm{t}$ at $0.6 \mathrm{~m}$. The pressure of the filling body fluctuated, decreased, and rose after $32.2 \mathrm{~m}$ behind the working face, forming a microgrowth trend. The lowest pressure was spotted at $45 \mathrm{~m}$ behind the working face, which may be caused by the main roof fracture. The pressure of the filling body changed little after $50 \mathrm{~m}$ behind the working face, indicating that the movement of roof strata tends to be stable.

\section{Law of Mine Pressure of the Gob-Side Entry Retaining during the Secondary Mining Period}

\subsection{Reinforcement Scheme Design of the Gob-Side Entry Retaining during Secondary Mining}

4.1.1. The Overall Grouting Scheme. The overall grouting scheme parameters and layout are shown in Table 5 and Figure 7, respectively.
4.1.2. Anchor Cable Reinforcement Scheme of E1316 Intake Entry. The anchor cable reinforcement scheme of E1316 intake entry is shown in Table 6 and Figure 8.

\subsection{Detection and Analysis of the Surrounding Rock Stability of Entry before the Secondary Mining}

4.2.1. Detection Scheme of the Surrounding Rock Structure. Based on the specific conditions of E1316 intake entry and air return entry, the borehole detector was used to detect and analyze the internal deformation and failure of the surrounding rock of entry, which provides a basis for entry evaluation and reinforcement scheme.

(1) The layout of the borehole stations: as shown in Figure 9(a), a CHK7.2 (B) type rock borehole detector developed by Xuzhou Whitton Company was adopted [17-19]. During the observation, the list of the required instruments is provided in Table 7 . 
TABLE 5: The details of the grouting parameters.

\begin{tabular}{lc}
\hline Related indicators & Parameters \\
\hline Grouting material & Jinan reinforcement I \\
Grouting form & Deep and shallow hole grouting \\
Grouting hole layout & Three-two layout \\
Grouting pressure & $0.7 \mathrm{MPa}$ (shallow hole), $2 \mathrm{MPa}$ (deep hole) \\
Grouting time per hole & $600 \mathrm{~s}$ \\
\hline
\end{tabular}

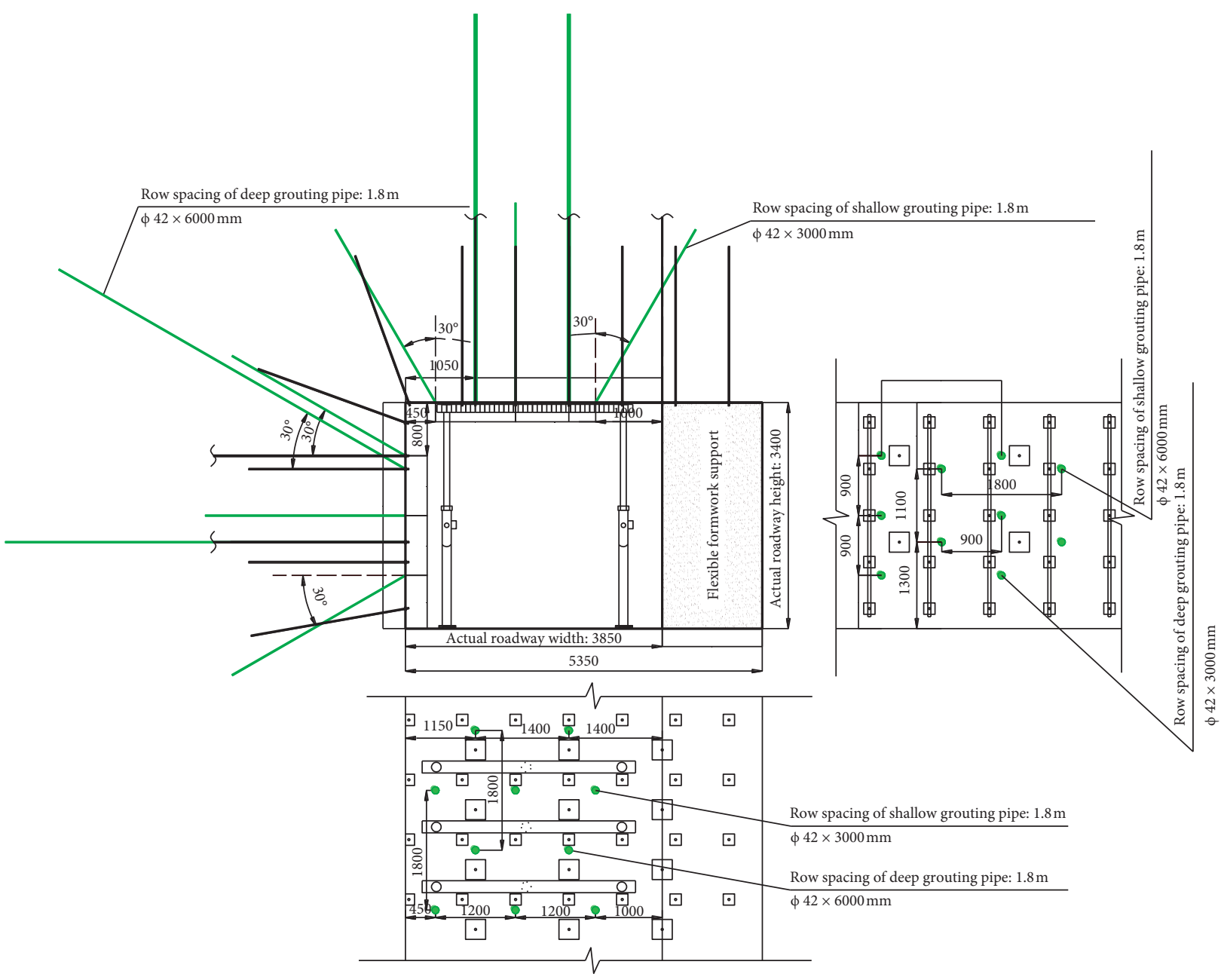

FIgURE 7: The layout of the grouting hole.

TABLE 6: The parameters of the cable reinforcement.

Name

Anchor cable specification

Pretightening force

Anchorage length

Resin explosive roll

Row and line space

Number

Tray specification

Mesh reinforcement

\section{Relevant parameters \\ $\Phi 18.96 \times 5300 \mathrm{~mm}$ \\ $\geq 163.3 \mathrm{kN}$ \\ $1657 \mathrm{~mm}$ \\ K2335(1), Z2360 (2)}

Coal side: $1400 \mathrm{~mm} \times 3600 \mathrm{~mm}$, Roof: $1700 \times 2700$

Coal side: $3 /$ row, Roof: $2 /$ row

$300 \mathrm{~mm} \times 300 \mathrm{~mm} \times 16 \mathrm{~mm}$

Ф6 steel bar, $100 \mathrm{~mm} \times 100 \mathrm{~mm}$ mesh (repair mesh only at failure point) 

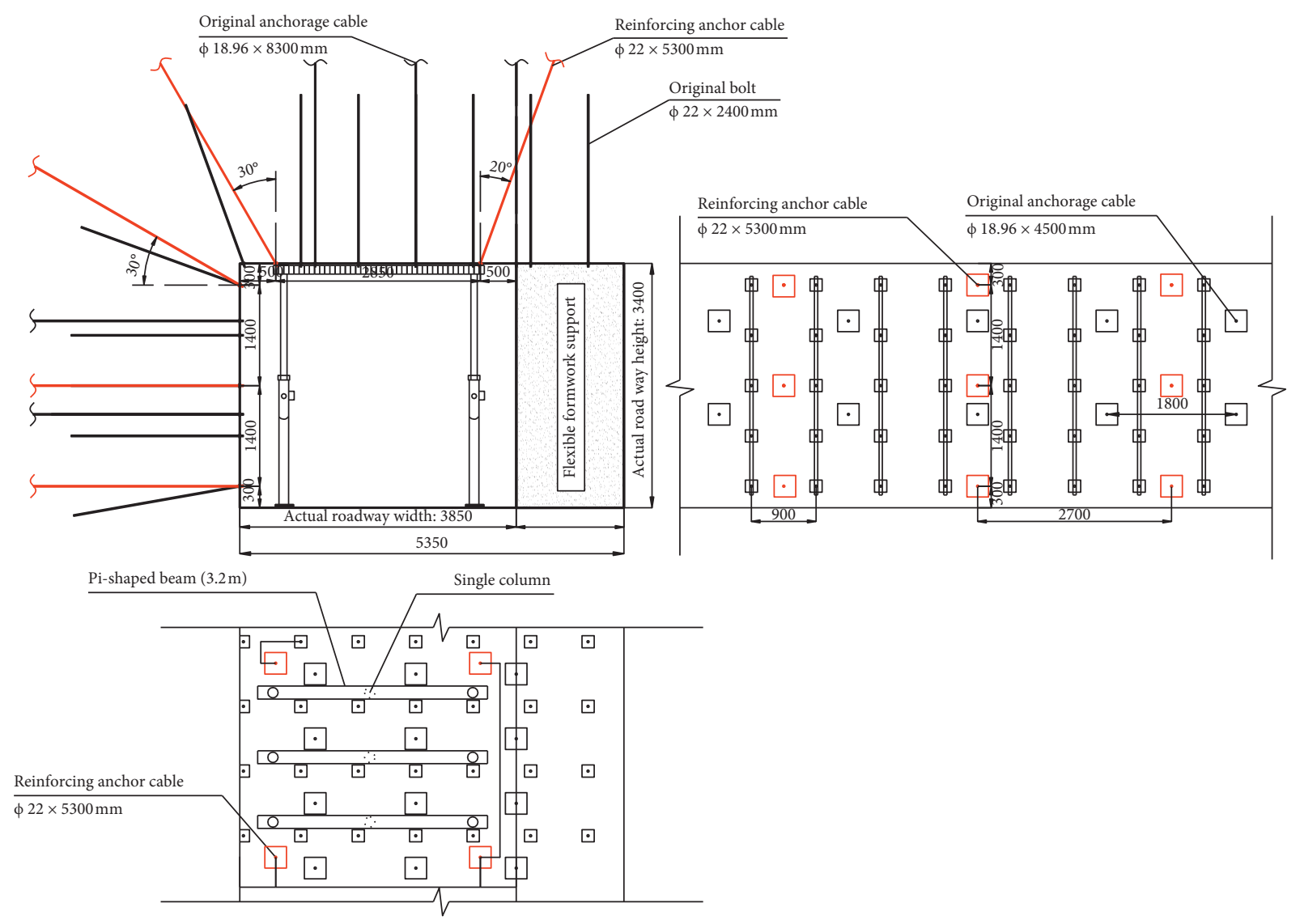

FIGURE 8: The schematic diagram of cable reinforcement of W1319 intake entry.
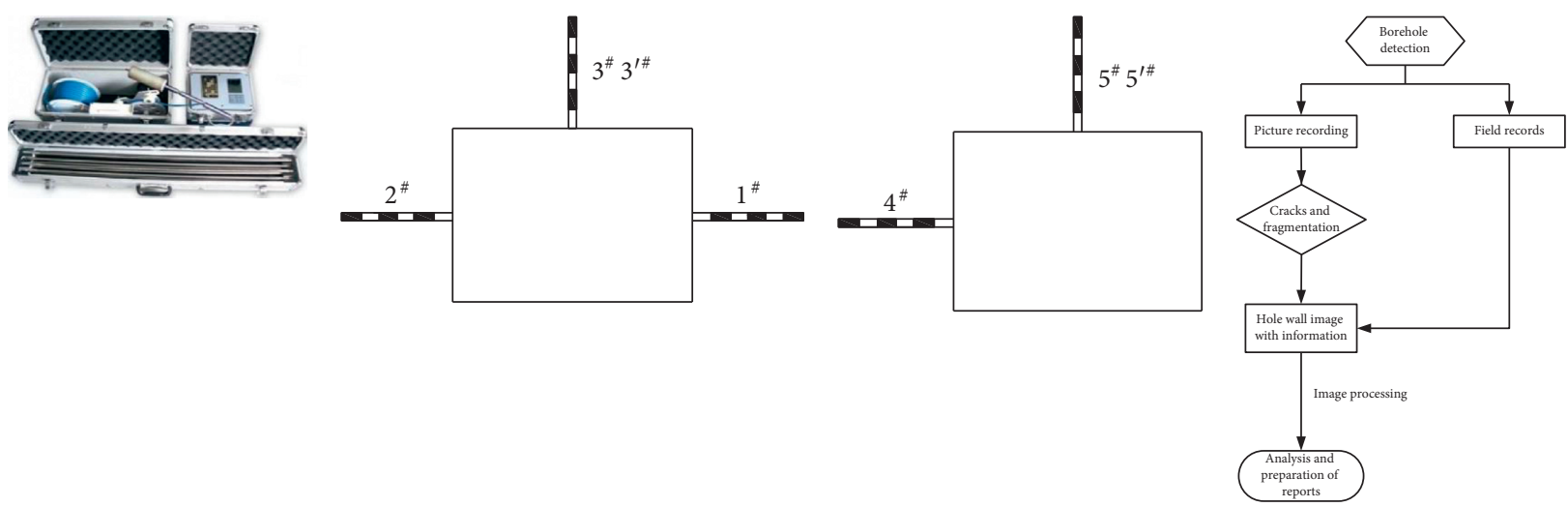

(a)

(b)

(c)

(d)

FIGURE 9: The detection scheme of the surrounding rock structure.

TABLE 7: The instrument list.

\begin{tabular}{lcc}
\hline Serial number & Instrument & Quantity \\
\hline 1 & CHK7.2 (B) type rock borehole detector & 1 \\
2 & Tape measure & 1 \\
\hline
\end{tabular}

(2) The observation content: the information regarding the internal deformation and the law governing the failure of the entry surrounding rock can be collected, as well as the development of the internal cracks in the entry surrounding rock, which has been proven to be effective in evaluating the entry support and providing reference for the optimization of entry support parameters. 
(3) Observation scheme: According to the specific production technical conditions of E1316 intake entry, the deformation and failure of surrounding rock were detected and analyzed by using the CHK7.2 (B) borehole detector in the early and middle working shifts on August 6, 2017. Boreholes were drilled along the roof of the entry upward and parallel to the floor along the pillar wall near E1316 intake entry, locating at 150 meters away from the cut hole. The boreholes' layout is shown in Figures 9(b) and 9(c).

A total of seven detection holes were drilled, namely, 1\# (E1316 air return entry coal pillar side), 2\# (E1316 air return entry solid coal side), 3\# and 3'\# (E1316 air return entry roof), 4\# (E1316 intake entry coal pillar side), and 5\# and 5'\# (E1316 intake entry roof). The design parameters of each detection hole are shown in Table 8.

(4) The borehole detection and analysis: as shown in Figure 9(d), converting the borehole video into screenshot images can facilitate the analysis and processing of the borehole wall. According to the specific production technical conditions of the related roadways in E1315 and E1316 working faces of Gaohe coal mine, the borehole detection was conducted in the early and middle shifts on August 6, 2017. Through the detection and analysis of the separation and deformation of the surrounding rock, seven observation holes were drilled, and four out of seven were obtained. Some boreholes failed in the middle of the drilling, which were abandoned and excluded. Overall, a total of 22 valid video images were obtained. The law governing the internal fissures development in the surrounding rock was presented, providing the foundation for the reinforcement scheme and the selection of the supporting system.

\subsubsection{Analysis of the Measurements}

(1) Due to the change of stress field in tunnel excavation, the shallow deformation and destruction of coal pillar in E1316 air return entry were severe, including the failures of the boreholes. The stress concentration of solid coal pillar was high with fully developed cracks in the coal body. The overall condition was featured with fractures and cracks in the coal roof. The mudstone and the deep rock mass remained intact.

(2) The coal body of the pillar side of E1316 intake entry was mostly loose from shallow to deep with limited cracks. The coal roof was severely fractured. The separation phenomenon was observed at the joint of coal seam with the mudstone, and the deep rock seam remained intact.

(3) The surrounding rock fragmentation of the two roadways gradually diffused from shallow to deep, and the degree of fragmentation gradually decreased from shallow to deep.

\subsection{Investigation on Premining Damage of Surrounding Rock and Flexible Formwork Filling Body of E1316 Gob-Side Entry Retaining}

4.3.1. Statistical Analysis of Entry Damage. In view of the situation of E1316 intake entry, the deformation and damage of coal pillar, roof, flexible formwork filling body, anchor cable, and ladder beam are counted from the cut hole of E1316 working face, as shown in Table 9.

According to the field investigation of E1316 intake entry, the main failure modes of entry include the bolt and cable failure, roof subsidence, coal pillar side moving towards the entry, severe coal body outburst at the shoulder corner of the entry, and bulging of the flexible formwork wall. The deformation mainly occurred in the roof and the coal pillar side. The estimated deformations reached about $450 \mathrm{~mm}$ and $300 \mathrm{~mm}$, respectively. The coal body outburst at the shoulder corner can reach $550 \mathrm{~mm}$. The analysis demonstrates that the deformation and destruction of the roof and the coal pillar side are severe. Meanwhile due to the high pressure, the coal pillar side and the flexible formwork wall failed. The existing supporting system faces the risk of uncontrollable entry deformations.

\subsubsection{Borehole Detection and Analysis}

(1) The roof of E1316 air return entry

(1) The distribution of the surrounding rock failure in the bolt anchorage zone presents progressive characteristics.

The surrounding rock in the $0.1-0.8 \mathrm{~m}$ range of the roof anchorage zone was seriously damaged, forming obvious fractured zones. The images were selected from the detection holes and are presented in Figures 10(a) and 10(b). The surrounding rock in the anchorage zone of roof was partially broken in the range of $1.1-2.0 \mathrm{~m}$, showing the plastic distribution and leading to the fracture zones with obvious development characteristics about $1 \mathrm{~m}$. Image presented in Figures $10(\mathrm{c})-10(\mathrm{f})$ were also selected from the detection holes.

(2) The development of the surrounding rock outside the bolt anchorage zone $(2.3-3.8 \mathrm{~m})$ fissures. In this range, obvious cracks and fragments were found in the surrounding rock. The coal-rock boundary was $3.8 \mathrm{~m}$. In other words, the top coal 
TABLE 8: Design parameters of boreholes for detection.

\begin{tabular}{lcccccc}
\hline NO & $1^{\#}$ & $2^{\#}$ & $3^{\#}$ & $3^{\#}$ & $4^{\#}$ & $5^{\#}$ \\
\hline Diameter $(\mathrm{mm})$ & $33 \sim 34$ & $33 \sim 34$ & $33 \sim 34$ & $33 \sim 34$ & $33 \sim 34$ & $33 \sim 34$ \\
Azimuth, $\alpha\left(^{\circ}\right)$ & -90 & 90 & - & - & 90 & - \\
Dip angle, $\beta\left(^{\circ}\right)$ & 0 & 0 & 90 & 90 & 0 & - \\
Length $(\mathrm{m})$ & 10 & 10 & 10 & 10 & 10 & 90 \\
\hline
\end{tabular}

No, 1 \# boreholes failed in the middle of drilling, which were abandoned and excluded.

TABLE 9: Questionnaire on deformation and failure of E1316 intake entry.

\begin{tabular}{|c|c|}
\hline $\begin{array}{l}\text { Mileage } \\
(\mathrm{m})\end{array}$ & Description of roadway damage \\
\hline $15 \sim 17$ & Flexible formwork wall is inserted upward \\
\hline $23,24,58$ & The coal body at the bottom of the coal pillar side is extruded $30-50 \mathrm{~cm}$, and the ladder beam is broken. \\
\hline 69 & Fracture of the ladder beam in coal pillar side. \\
\hline 78 & Flexible formwork wall bulge phenomenon. \\
\hline $82 \sim 84,100$ & Fracture of the ladder beam in coal pillar side. \\
\hline $103 \sim 105$ & Metal net at the lower part of coal pillar side cracking, ladder beam fracture, and flexible formwork wall cracking. \\
\hline 113 & The bolt of the coal pillar side failed, and the cables were laid beside it. \\
\hline 118 & Fracture of the ladder beam near the second bolt at the bottom of coal pillar side. \\
\hline 132 & Cracking of entry floor. \\
\hline $151 \sim$ & Two bolts in the middle of coal pillar side are pulled out by the mining stress. \\
\hline 163 & Anchoring cable for pillar reinforcement has been removed in later period. \\
\hline $175 \sim 180$ & Extrusion and crushing at shoulder corner of the roof and coal pillar side is serious. \\
\hline 188 & Unanchoring of the third bolt from the bottom of the coal pillar side. \\
\hline $190-214$ & Cracking of entry floor. \\
\hline $198 \sim 201$ & Four rows of ladder beams were broken in the middle and lower parts of coal pillar side. \\
\hline 213 & $\begin{array}{c}\text { The flexible formwork wall cracks in a 3-square range, the ladder beam at the bottom of the coal pillar side was broken, and } \\
\text { the roof protruded seriously. }\end{array}$ \\
\hline 221 & Two failure bolt \\
\hline $229 \sim 232$ & The upper and lower parts of the flexible formwork wall fall into the bag. The height is 1.2 meters, and the length is 4.5 meters. \\
\hline 239 & $\begin{array}{l}\text { The second bolt dynamometer reading at the bottom of the coal pillar wall is } 24 \mathrm{MPa} \text {, which is abnormal; the flexible } \\
\text { formwork wall cracks, and the middle part falls into the bag. }\end{array}$ \\
\hline $247 \sim 253$ & $\begin{array}{c}\text { The damage and deformation of coal pillar side are serious, which are mainly affected by primary mining and adjacent } \\
\text { chambers. }\end{array}$ \\
\hline 259 & Roof breakage and subsidence are very seric \\
\hline 276 & Unanchoring of the third a \\
\hline 296 & Unanchoring of the third bolt from the bot \\
\hline 308 & Unanchoring of the second bolt from the bottom of the coal pillar side. \\
\hline & Unanchoring of the second bolt from the bottom of the coal pillar side. \\
\hline 32 & The upper part of flexible formwork wall badly bulge phenomenon. \\
\hline & Flexible formwork wall with bulge phenomenon, bulging range is 2 meters. \\
\hline $352-$ & Cracking of the flexible formwork wall is serious. \\
\hline 358 & The second repaired cable at the bottom of the coal pillar side has failed. \\
\hline 399 & Cracking of entry floor. \\
\hline 422 & e are timbers to strengthen support in this area, and there at \\
\hline$\sim 479$ & Over-excavation of coal pillar side is serio \\
\hline 537 & The roof is broken seriously, the displacement is large, and the flexible formwork wall has bulging problem. \\
\hline 581 & Unanchoring of the third bolt from the bottom of the coal pillar side. \\
\hline 583 & Unanchoring of the second bolt from the bottom of the coal pillar side. \\
\hline 620 & $\begin{array}{l}\text { The upper part of the flexible formwork wall bulges and cracks, and the third anchor bolt is removed from the bottom of the } \\
\text { coal pillar side. }\end{array}$ \\
\hline & Water accumulation \\
\hline 652 & The upper part of the flexible formwork wall is bulging within 2 meters. \\
\hline
\end{tabular}

thickness is $3.8 \mathrm{~m}$. Compared with the coal seam column diagram and the situation of excavation, the top coal thickness fluctuated greatly with a thicker top. The detection results are shown in Figures 11(a)-11(d).
(3) The development of the surrounding rock outside the bolt anchorage zone $(3.8-10 \mathrm{~m})$ is in the basic integrity state.

In this range, no obvious cracks and fractured zones were found in the surrounding rock with the good integrity. 


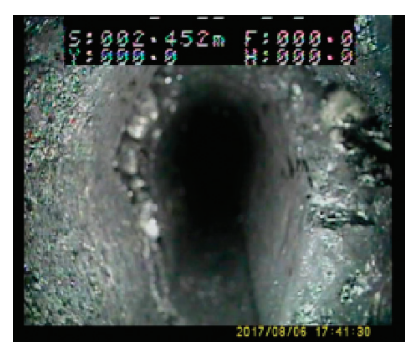

(a)

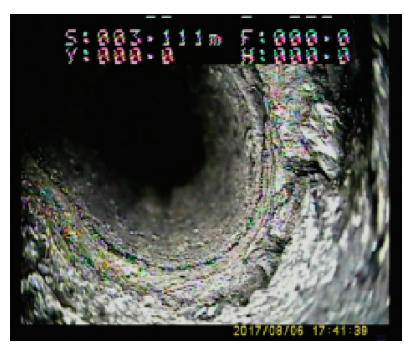

(b)

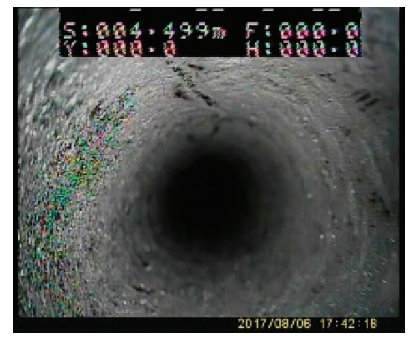

(e)

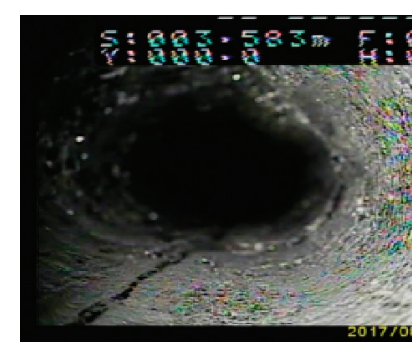

(c)

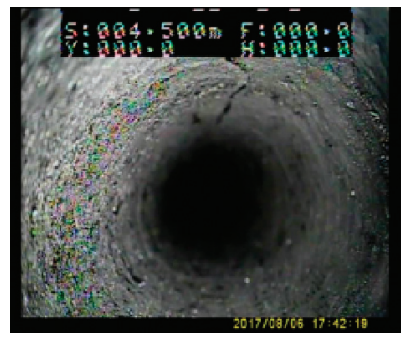

(f)

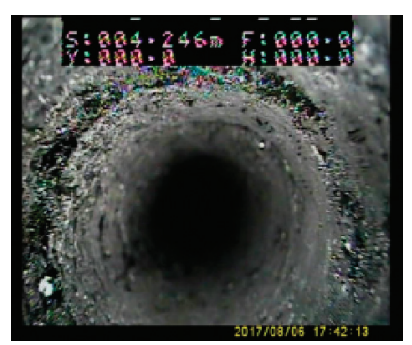

(d)

FIGURE 10: The distribution of the surrounding rock in the roof anchorage area. (a) $0.2 \mathrm{~m}$. (b) $0.8 \mathrm{~m}$. (c) $1.1 \mathrm{~m}$. (d) $1.5 \mathrm{~m}$. (e) $1.8 \mathrm{~m}$. (f) $2.0 \mathrm{~m}$.

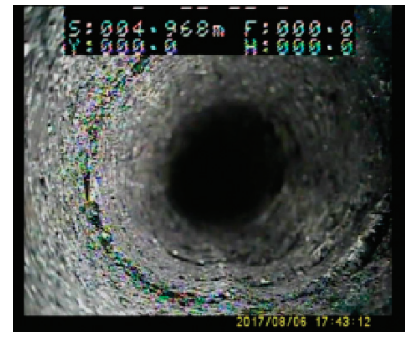

(a)

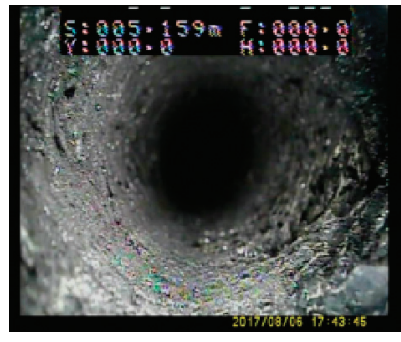

(b)

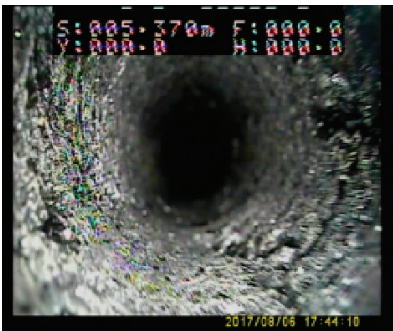

(c)

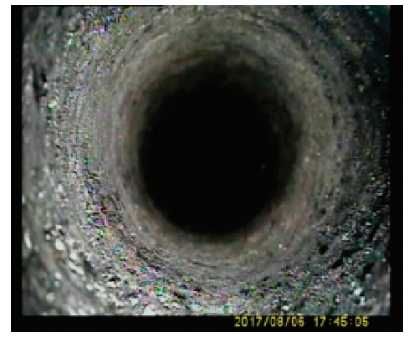

(d)

FIgURE 11: The distribution of the surrounding rock $(2.5-3.8 \mathrm{~m})$ outside the anchor zone. (a) $2.5 \mathrm{~m}$. (b) $2.9 \mathrm{~m}$. (c) $3.4 \mathrm{~m}$. (d) $3.8 \mathrm{~m}$.

The hole with the depth of $7.2 \mathrm{~m}$ was located at the junction of the direct roof and the main roof, which was relatively fragmented. A large amount of smoke and dust in the hole was within the main roof, due to the friction between the drill bit and the sandstone of the main roof. The helix characteristics were clearly observed. The detection results are shown in Figures 12(a)-12(h).

(2) The solid coal side of E1316 return entry

(1) Good integrity of the surrounding rock in the bolt anchorage zone.

In this range, no obvious cracks and fractured zones were found in the surrounding rock with better integrity. The preload of the bolt support was high at the initial stage. Better supporting effects were identified in the bolting range. This range of images was selected from the detection hole, and the results are shown in Figures 13(a)-13(d).

(2) Fracture zones found in the surrounding rock outside the bolt anchorage zone $(2.3-7.8 \mathrm{~m})$. In this range, obvious crack development and fragmentation were found in the surrounding rock. The coal body was loose and fragmented, accompanied by severe granular coal caving. The detection results are shown in Figures 14(a)14(d).

(3) Good surrounding rock integrity outside the bolt anchorage zone $(7.8-10 \mathrm{~m})$.

In this range, no obvious cracks and fractured zones in the surrounding rock due to unmined working face were present. The overall integrity remained untouched. The coal powder accumulation in the pillar side hole was severe. This range of images was selected from the detection hole, and the results are shown in Figures 15(a)-15(d).

(3) The roof of E1316 intake entry.

(1) Fractured zones found in the surrounding rock of bolt anchorage zone

The integrity of the surrounding rock in $0.1-0.7 \mathrm{~m}$ range of the roof anchorage zone was good. The detection results are shown in Figures 16(a) and 16(b). The surrounding rock in $0.7-2.3 \mathrm{~m}$ range of the roof anchorage zone was partially broken, and the cracks had expanded and developed. This range of images was selected 


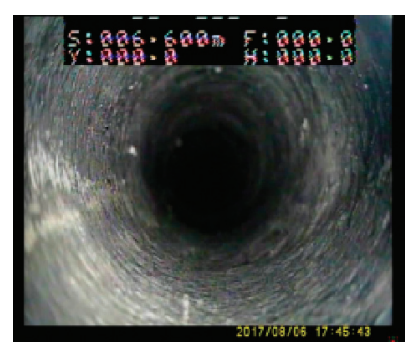

(a)

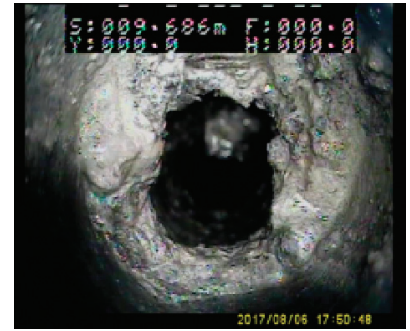

(e)

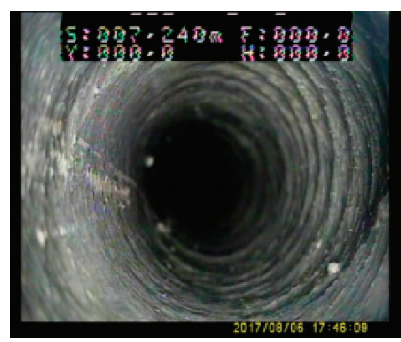

(b)

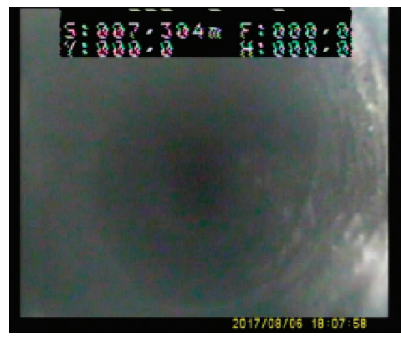

(f)

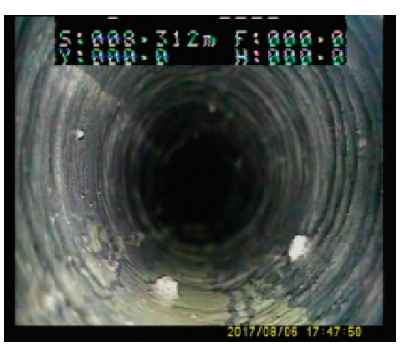

(c)

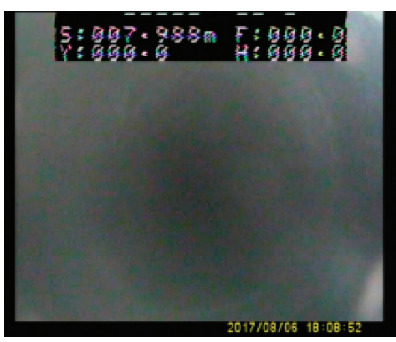

(g)

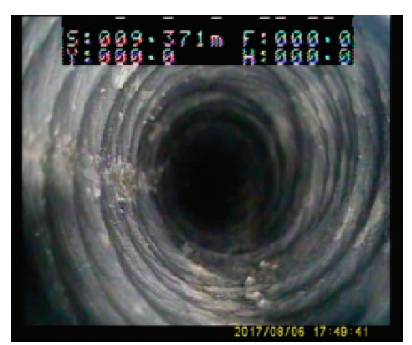

(d)

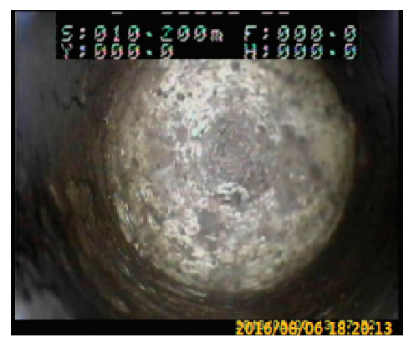

(h)

Figure 12: The distribution of the surrounding rock (3.8-10 m) outside the anchor zone. (a) $4.1 \mathrm{~m}$. (b) $4.7 \mathrm{~m}$. (c) $5.9 \mathrm{~m}$. (d) $6.9 \mathrm{~m}$. (e) $7.2 \mathrm{~m}$. (f) $7.6 \mathrm{~m} .(\mathrm{g}) 8.0 \mathrm{~m}$. (h) $10.0 \mathrm{~m}$.

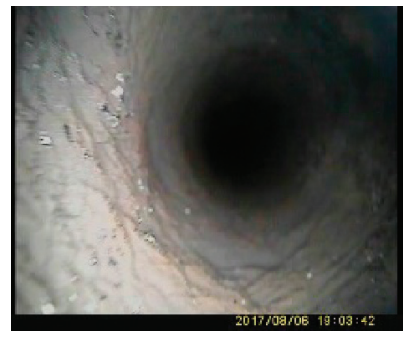

(a)

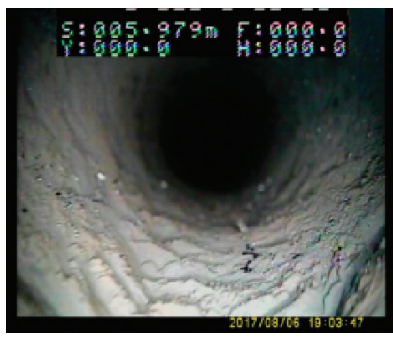

(b)

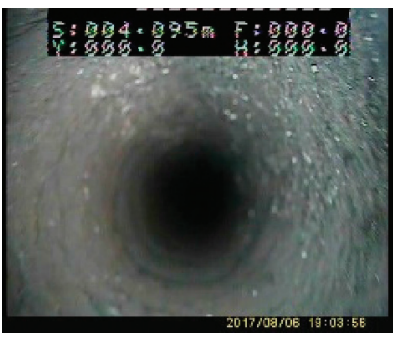

(c)

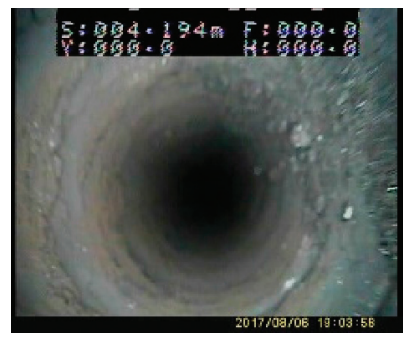

(d)

FIGURE 13: The distribution of the surrounding rock in the roof anchorage area. (a) $0.2 \mathrm{~m}$. (b) $0.9 \mathrm{~m}$. (c) $1.8 \mathrm{~m}$. (d) $2.2 \mathrm{~m}$.

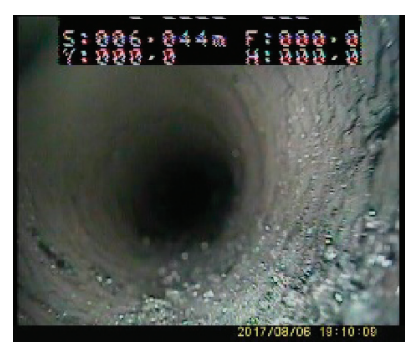

(a)

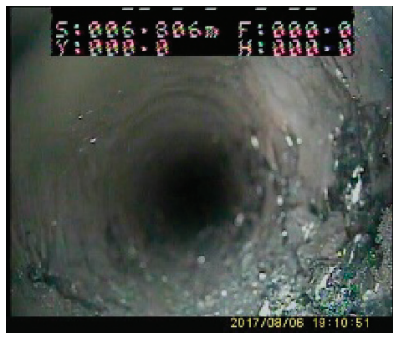

(b)

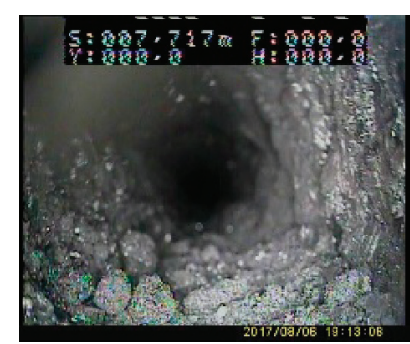

(c)

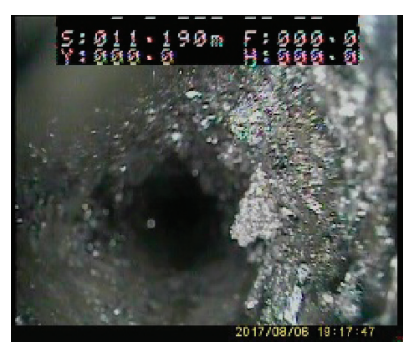

(d)

FIGURE 14: The distribution of the surrounding rock $(2.3-7.8 \mathrm{~m}$ ) outside the anchor zone. (a) $2.6 \mathrm{~m}$. (b) $4.2 \mathrm{~m}$. (c) $5.8 \mathrm{~m}$. (d) $7.6 \mathrm{~m}$.

from the detection hole, and the results are shown in Figures 16(c)-16(f).

(2) The development of the surrounding rock outside the bolt anchorage zone $(2.3-2.8 \mathrm{~m})$ fissures Fissure zones were identified in the surrounding rock. The fissures developed initially from $1.7 \mathrm{~m}$ in the anchorage area with a 1.1-meter penetration. Due to the softness differences between the coal body and the drill bit, the fissures can develop during drilling, and the coal-rock interface is $2.8 \mathrm{~m}$. The detection results are shown in Figures $17(\mathrm{a})-17(\mathrm{~d})$. 


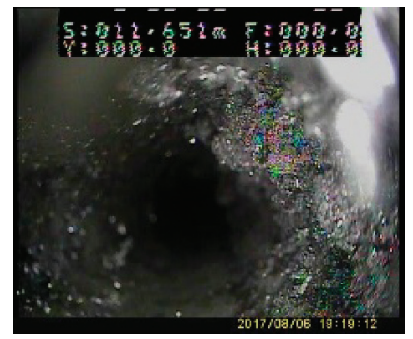

(a)

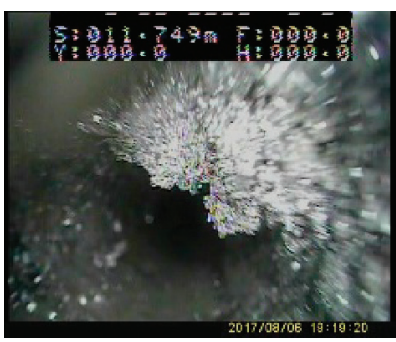

(b)

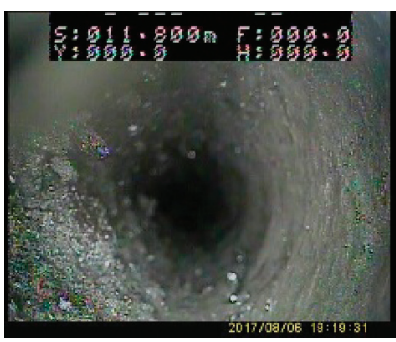

(c)

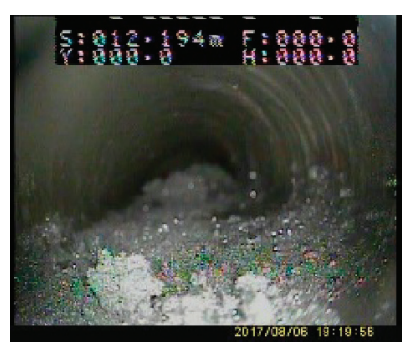

(d)

Figure 15: The distribution of the surrounding rock $(7.8-10 \mathrm{~m}$ ) outside the anchor zone. (a) $7.9 \mathrm{~m}$. (b) $8.3 \mathrm{~m}$. (c) $9.2 \mathrm{~m}$. (d) $10.0 \mathrm{~m}$.

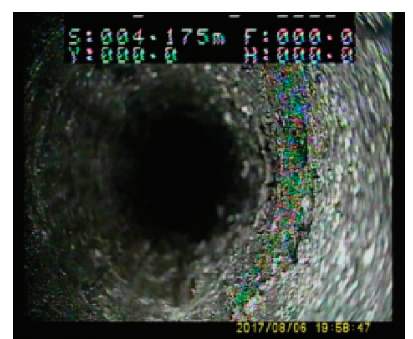

(a)

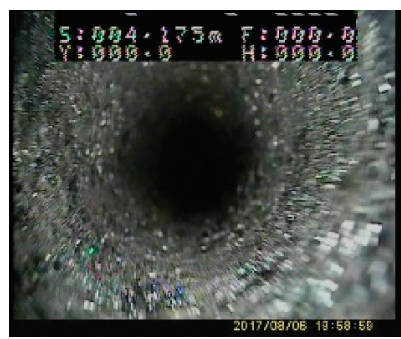

(b)

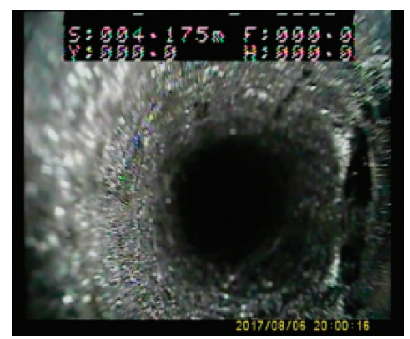

(e)

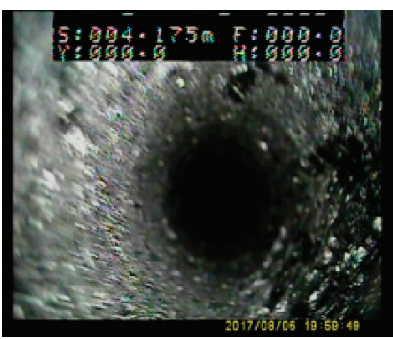

(c)

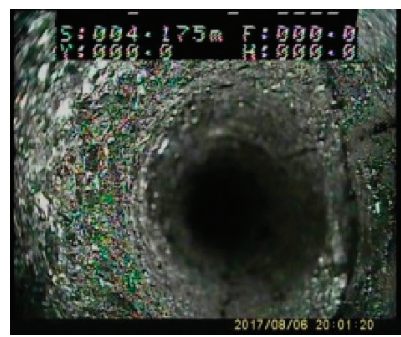

(f)

Figure 16: The distribution of the surrounding rock in the roof anchorage area. (a) $0.2 \mathrm{~m}$. (b) $0.7 \mathrm{~m}$. (c) $0.8 \mathrm{~m}$. (d) $1.0 \mathrm{~m}$. (e) $1.8 \mathrm{~m}$. (f) $2.2 \mathrm{~m}$.

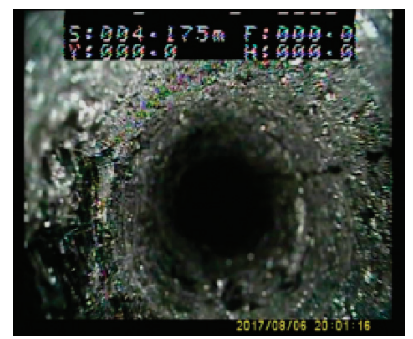

(a)

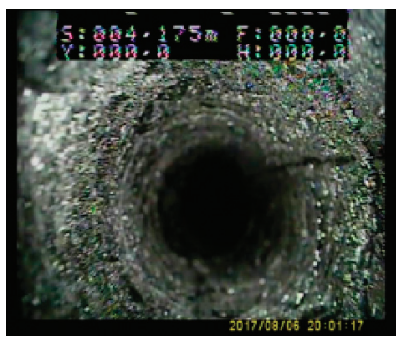

(b)

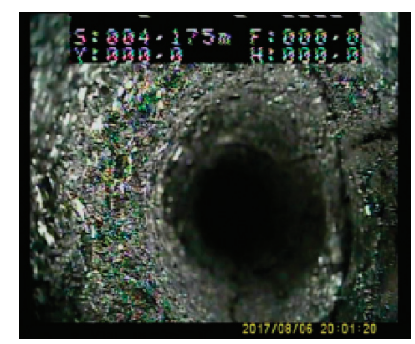

(c)

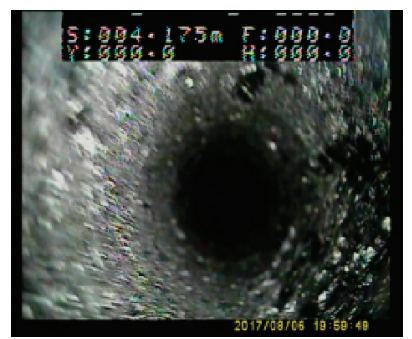

(d)

Figure 17: The distribution of the surrounding rock $(2.3-2.8 \mathrm{~m}$ ) outside the anchor zone. (a) $2.3 \mathrm{~m}$. (b) $2.5 \mathrm{~m}$. (c) $2.7 \mathrm{~m}$. (d) $2.8 \mathrm{~m}$.

(3) The development of the surrounding rock outside the bolt anchorage zone $(2.8-10 \mathrm{~m})$ with basic integrity.

In this range, no obvious cracks and fractured zones were found in the surrounding rock with good integrity. The hole with a $5.7 \mathrm{~m}$ depth was located at the junction of the direct top and the main roof, which was relatively fragmented. The surrounding rock in the hole was intact within the main roof without any crack. The drilling process took longer. The fine sandstone of the main roof was harder, and the helix characteristics were visible. The detection results are shown in Figures 18(a)-18(h).

(4) The solid coal side of E1316 intake entry.

(1) Good integrity of the surrounding rock in bolt anchorage zone. 


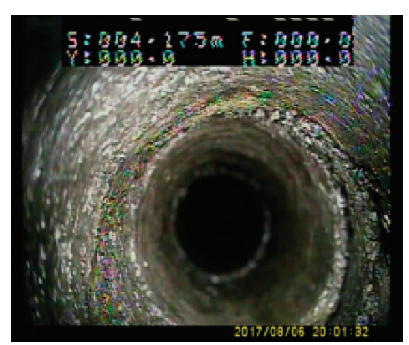

(a)

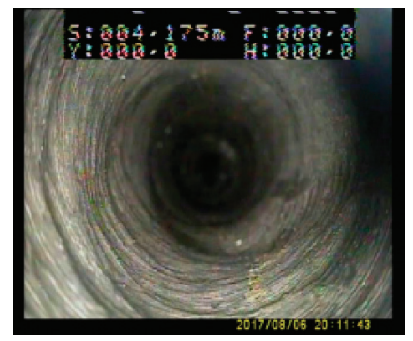

(e)

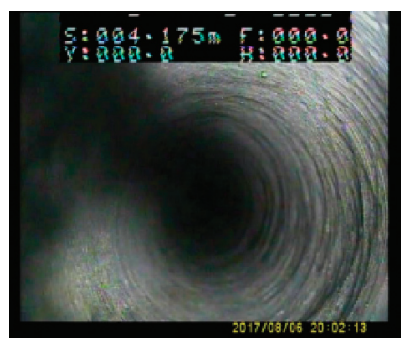

(b)

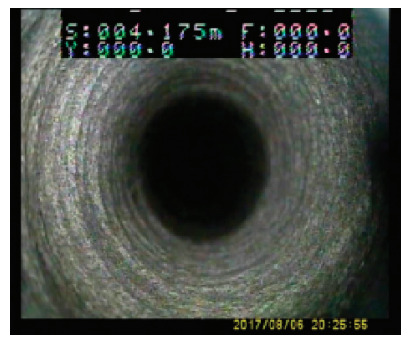

(f)

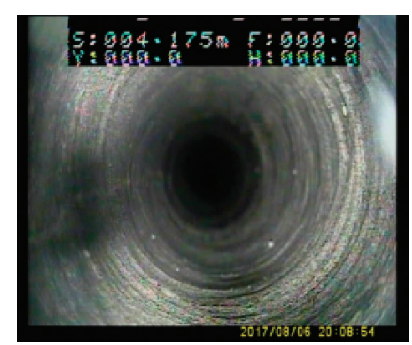

(c)

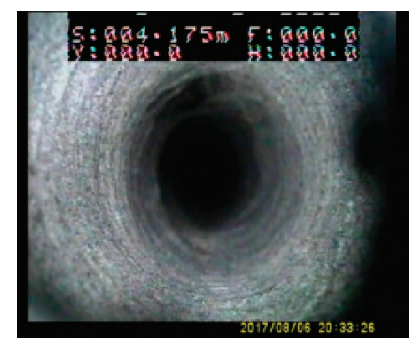

(g)

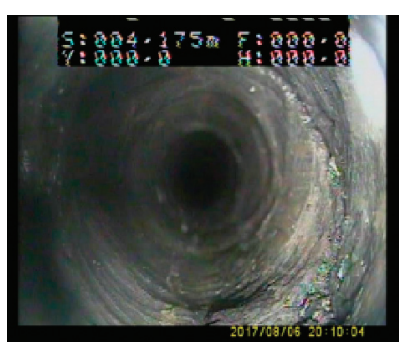

(d)

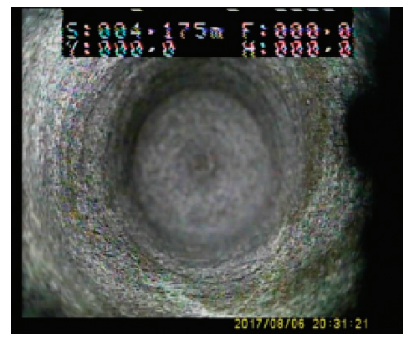

(h)

FIGURE 18: The distribution of the surrounding rock $(2.8-10 \mathrm{~m}$ ) outside the anchor zone. (a) $2.9 \mathrm{~m}$. (b) $3.4 \mathrm{~m}$. (c) $4.0 \mathrm{~m}$. (d) $5.7 \mathrm{~m}$. (e) $6.4 \mathrm{~m}$. (f) $7.5 \mathrm{~m}$. (g) $8.8 \mathrm{~m}$. (h) $10.0 \mathrm{~m}$.

In this range, no obvious cracks and fractured zones in the surrounding rock were found, but the coal body is loose and had no bearing capacity. This range of images was selected from the detection hole, and the results are shown in Figures 19(a)-19(d)

(2) The fracture zone in the surrounding rock outside bolt anchorage zone.

No obvious characteristics of crack development and fragmentation were found in the surrounding rock. Due to the high lateral stress caused by the mining in the upper working face, borehole fragmentation and deformation were severe with poor integrity. This range of images was selected from the detection hole, and the results are shown in Figures 20(a)-20(h).

\subsection{Comprehensive Assessment on the Premining Damage of Surrounding Rock and Flexible Formwork Filling Body of E1316 Gob-Side Entry Retaining}

4.4.1. Analysis of the Main Roof Structure. Combining with the statistical analysis of entry damage and field investigation results of borehole detection in the previous section, the overburden structure of E1316 intake entry changed due to the mining of E1315 working face. During the advancing process of E1315 working face, the periodic weighting phenomena occurred in the roof. After the first weighting, the continuous advancing of the working face had made the main roof of E1315 working face prone to form "O-X" fracture structure. Due to the top coal collapse and the 2.6meter thick immediate roof, the main roof was suffering from the fracture, rotation, and subsidence. In the mining process of E1315 working face, the flexible formwork support was used to ensure the safety of gob-side entry retaining. Before the mining of E1316 working face, under the overall structural environment of the goaf, flexible formwork wall, and E1316 intake entry, the main roof of the section direction of E1316 intake entry can temporarily form a masonry beam structure. The fracture structure was often caused by many factors including the thickness and mechanical properties of the main roof, the immediate roof, and the coal seam, the mining depth, the stress state of the original rock, and the mining height [20-22].

According to the features of the failures of the roof of E1316 intake entry, the main roof failed at the "masonry beam" and the breaking line was above E1316 working face, suggesting that most of the weight of rock block B was above E1316 intake entry. In addition, the weight was borne by the flexible formwork wall and the coal pillar, which made the support of entry more difficult.

4.4.2. Location Analysis of the Main Roof Fracture. The location of the fracture in the main roof of the E1316 intake entry holds an important role in the stability of the surrounding rock. Under the lateral abutment pressure of the working face, plastic zone, elastic zone, and original rock stress zone tend to appear from the edge of the coal pillar side of the entry to the depth of the coal pillar. The fracture position of the main roof was located near the junction of the elastic zone and the plastic zone in the coal body, as shown in Figure 21.

In the plastic zone, the fracture of the coal pillar was fully developed and the damage was severe. On the contrary, the damage in the elastic zone and original rock stress zone was limited. The depth of plastic zone affects the selection of support parameters. Therefore, the limit equilibrium theory was adopted to calculate the depth of the plastic zone of the 


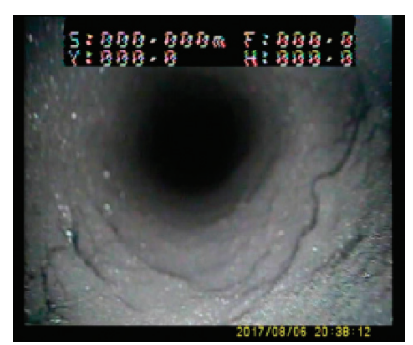

(a)

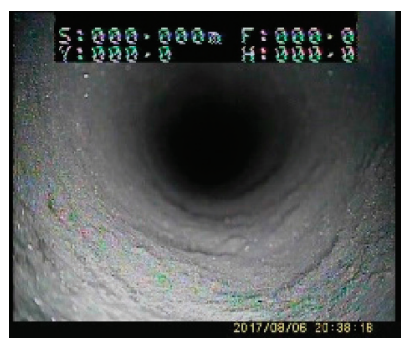

(b)

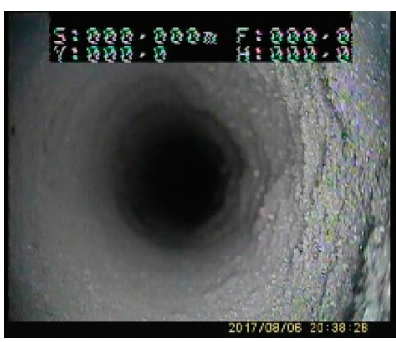

(c)

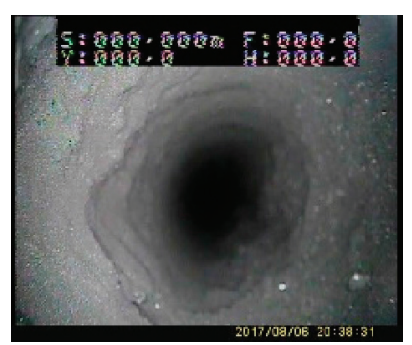

(d)

FIGURE 19: The distribution of the surrounding rock in the roof anchorage area. (a) $0.2 \mathrm{~m}$. (b) $0.8 \mathrm{~m}$. (c) $1.6 \mathrm{~m}$. (d) $2.2 \mathrm{~m}$.

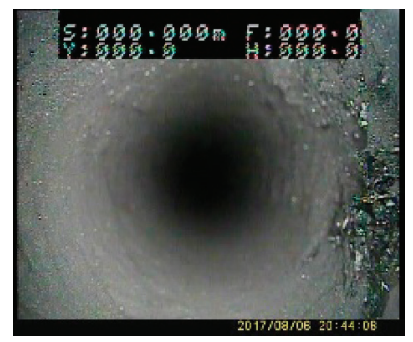

(a)

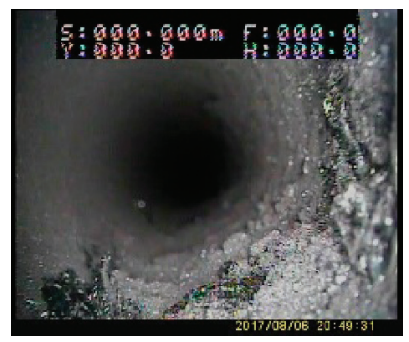

(e)

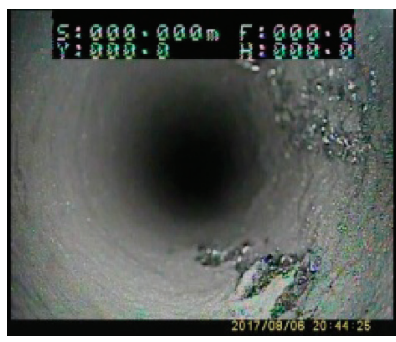

(b)

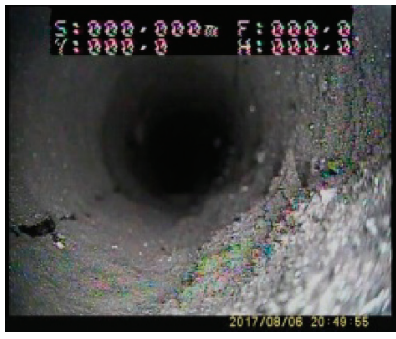

(f)

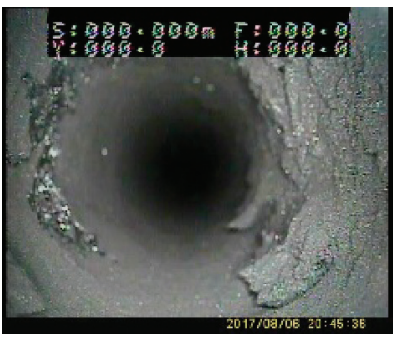

(c)

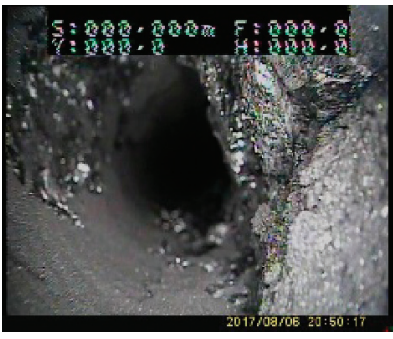

(g)

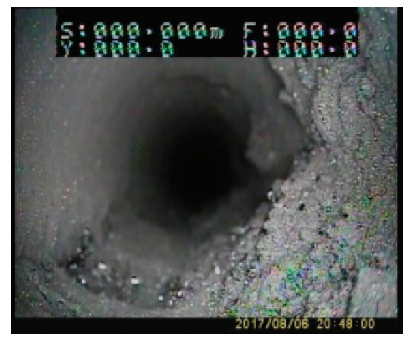

(d)

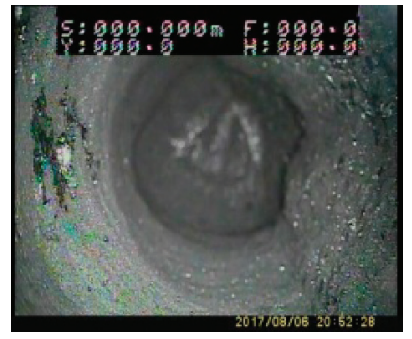

(h)

FiguRE 20: The distribution of the surrounding rock outside the anchor zone. (a) $2.6 \mathrm{~m}$. (b) $3.2 \mathrm{~m}$. (c) $4.8 \mathrm{~m}$. (d) $5.6 \mathrm{~m}$. (e) $6.6 \mathrm{~m}$. (f) $7.8 \mathrm{~m}$. (g) $8.9 \mathrm{~m}$. (h) $10.0 \mathrm{~m}$.

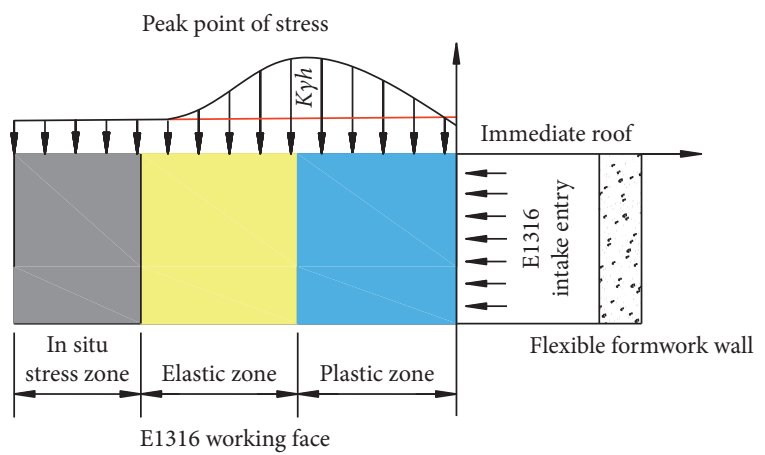

FIGURE 21: The diagrammatic sketch of stress distribution in coal pillar side.

surrounding rock for dynamic mining pressure entry such as E1316 intake entry.

According to the calculation, the limit equilibrium zone depth of E1316 intake entry was $6.14 \mathrm{~m}$. In other words, the junction point of the plastic zone and elastic zone on the coal pillar side of E1316 intake entry was
$6.14 \mathrm{~m}$ away from the coal wall. The calculation suggests that the breaking line of key block B of the main roof was above the coal pillar, which was about $6.14 \mathrm{~m}$ away from the coal wall.

4.4.3. Comprehensive Assessment of E1316 Gob-Side Entry Retaining. The measurement of rock mechanics properties, detection of the surrounding rock structure, and statistical study and theoretical calculation of premining failure of the surrounding rock and the flexible formwork filling body of E1316 gob-side entry retaining have suggested that the surrounding rock of E1316 intake entry had undergone great deformation and destruction. The serious damage of support structure had made the supporting system more vulnerable and fragile. In addition, due to the uneven occurrence of the layered surrounding rock, the uneven roadside support, and coal rib support, the deformation and failure of the support structure of gob-side entry retaining present nonuniform characteristics. The instability of the support structure can be jeopardized due to the significant deformation and failure occurred in the entry. 
In view of the existing problems, the following solutions are proposed as follows:

(1) To solve the problem of loose bolts, the twin-nut structure is suggested. In addition, the bolt supporting density and anchoring agent should be increased to enhance the length of grip.

(2) To minimize the risk of ladder beam fracture, the ladder beam should be reinforced with the $16 \mathrm{~mm}$ round steel. The stress on the ladder beam should be verified. Regarding the continuous fracture area, the ladder beam can be replaced by using the steel strip for increased surface areas and strength.

(3) To minimize the risk of pallet failure, the $200 \times 200 \times 15 \mathrm{~mm}$ bolt pallets and the $350 \times 350 \times 18 \mathrm{~mm}$ cable pallets should be adopted. In addition, the wooden pallets and No. 12\# lead wire meshes should be added to increase the surface area of pallets.

(4) To minimize the bulging and fracturing of the flexible formwork wall, a series of reinforcements and support measures for point pillars along the flexible formwork walls in the entry should be added.

(5) To minimize the floor heave of the entry, excavation measures should be taken in the floor heave.

The comprehensive analysis indicates that E1316 intake entry is subject to a high superimposed stress. Due to the low strength of the coal and rock mass, the surrounding rock cracks developed and continued to expand. With the poor bearing capacity of the entry itself, the flexible formwork wall tends to crack easily. Therefore, besides the proposed reinforcements and other preventative measures, monitoring the mine pressure constantly plays a vital role in ensuring the safety of the roadway and the E1316 working face.

\section{Conclusion}

(1) During the initial mining period, the roadway located at the stress increasing area was affected by mining in E1315 working face. The observation and analysis have suggested that the high pressure caused severe damage to the surrounding rock and the flexible formwork filling wall in the upper section of the entry. The roof and the flexible formwork wall experienced various levels of damage.

(2) The flexible formwork filling wall provides great strength with poor contractibility. For the severe roof subsidence at the gob-side entry retaining, the hardness of the filling wall was not compatible with the coal roof, resulting in inconsistent deformation. The deformation eventually led to the failure of the coal roof and flexible formwork filling wall, jeopardizing the entry support.

(3) The mining and roof collapse of E1315 working face lead to the formation of long cantilever beams which are not easy to collapse in the goaf on the side of the flexible formwork wall of E1316 intake entry. Most of its own weight of the cantilever beams acts on the flexible formwork filling wall, support structure, and coal pillar side, and the overall structure of the entry experienced various levels of damages.

(4) Due to the high stress, cracks developed in the top coal and the immediate roof rock layer $(2.65 \mathrm{~m}$ above the entry), which continued to expand until the failure of the surrounding rock. Meanwhile, the coal pillar grew loose and fragmented beyond the range of $5 \mathrm{~m}$. The deformation made the coal pillar become uneven and fragile, resulting in the moving out of the whole coal pillar. The deformation further jeopardized the bearing capacity of the surrounding rock. The coal pillar side experienced the most severe damage.

(5) With the reinforcements in the roof and the pillar side of the entry, the entry damage and deformation can be contained. However, more maintenance was required. Multiple long cracks and heaves were found in the immediate floor where no reinforcements were added.

The study of the coal pillarless mining technology conducted can provide both theoretical and pragmatic references to the operation of No. 3\# coal in the entire Luan mining area, as well as other mining locations sharing similar conditions in Qinshui coalfield. The wide adoption of the gob-side entry retaining technology in the Luan mining area or Qinshui coalfield can bring significant economic and social benefits.

\section{Data Availability}

The data used to support the findings of this study are included within the article. And all data are obtained through experiment and test by our research team in Gaohe mine and laboratory. All the data are true and effective. The right to using data belongs to the authors before the article being published, but after it was published, the data can be referenced.

\section{Conflicts of Interest}

The authors declare no conflicts of interest.

\section{Acknowledgments}

The authors thank Shuai Zhu, Minglei Zhang, and Xinwen $\mathrm{Du}$ of the research group for their help in completing this paper. They have done a lot of preliminary work in the related projects of the paper. This work was supported by 2014 Shanxi Province Coal-Based Key Scientific and Technological Projects Bidding Announcement (MJ2014-12); the Natural Science Foundation of China (nos. 51909204 and 11802218); Science and Technology Plan Project of Shaanxi Province (no. 2019JQ-432); Shaanxi Key Laboratory of Loess Mechanics and Engineering (no. LME201801); the Natural Science Foundation of Shaanxi Provincial Department of Education (no. 20JK0670); and Jiangsu Construction System Science and Technology Project (Guidance) (no. 2019ZD080). 


\section{References}

[1] F.-T. Zhang, X.-Y. Wang, J.-B. Bai, G.-Y. Wang, and B.-W. Wu, "Post-peak mechanical characteristics of the highwater material for backfilling the gob-side entry retaining: from experiment to field application," Arabian Journal of Geosciences, vol. 13, no. 11, p. 386, 2020.

[2] G.-feng Zhang et al., "Research on the technique of no-pillar mining with gob-side entry formed by advanced roof caving in the protective seam in Baijiao coal mine," Journal of Mining and Safety Engineering, vol. 28, no. 4, pp. 511-516, 2011.

[3] Li Huamin, "Control design of roof rocks for gob side entry," Chinese Journal of Rock Mechanics and Engineering, vol. 19, no. 5, pp. 651-654, 2000.

[4] Z. Luo, Q. Hao, T. Wang, R. Li, F. Cheng, and J. Deng, "Experimental study on the deflagration characteristics of methane-ethane mixtures in a closed duct," Fuel, vol. 259, Article ID 116295, 2020.

[5] Z. Luo, R. Li, T. Wang et al., "Explosion pressure and flame characteristics of $\mathrm{CO} / \mathrm{CH} 4 /$ air mixtures at elevated initial temperatures," Fuel, vol. 268, Article ID 117377, 2020.

[6] Z. Zhang, M. Deng, X. Wang, W. Yu, F. Zhang, and V. D. Dao, "Field and numerical investigations on the lower coal seam entry failure analysis under the remnant pillar," Engineering Failure Analysis, vol. 115, Article ID 104638, 2020.

[7] A. Jaiswal and B. K. Shrivastva, "Numerical simulation of coal pillar strength," International Journal of Rock Mechanics and Mining Sciences, vol. 46, no. 4, pp. 779-788, 2009.

[8] E. Ghasemi, M. Ataei, K. Shahriar, F. Sereshki, S. E. Jalali, and A. Ramazanzadeh, "Assessment of roof fall risk during retreat mining in room and pillar coal mines," International Journal of Rock Mechanics and Mining Sciences, vol. 54, pp. 80-89, 2012.

[9] M. C. He, "Control of surrounding rock structure for gob-side entry retaining by cutting roof to release pressure and its engineering application," Journal of China University of Mining and Technology, vol. 46, no. 5, pp. 959-969, 2017.

[10] M. C. He, "An energy-gathered roof cutting technique in nopillar mining and its impact on stress variation in surrounding rocks," Chinese Journal of Rock Mechanics and Engineering, vol. 36, pp. 1314-1325, 2017.

[11] Y. Xu, J. Chen, and J. Bai, "Control of floor heaves with steel pile in gob-side entry retaining," International Journal of Mining Science and Technology, vol. 26, no. 3, pp. 527-534, 2016.

[12] Y.-F. Li and X.-Z. Hua, "Mechanical analysis of stability of key blocks of overlying strata for gob-side entry retaining and calculating width of roadside backfill," Rock and Soil Mechanics, vol. 33, no. 4, pp. 1134-1140, 2012.

[13] H. P. Kang, "In-situ stress measurements and distribution laws in Lu'an underground coal mines," Rock and Soil Mechanics, vol. 3, 2010.

[14] Y. Wang, Y. Gao, E. Wang, M. He, and J. Yang, "Roof deformation characteristics and preventive techniques using a novel non-pillar mining method of gob-side entry retaining by roof cutting," Energies, vol. 11, no. 3, p. 627, 2018.

[15] X. Zhu, "Research on the stability evaluation model of composite support pillar in backfill-strip mining," Mathematical Problems in Engineering, vol. 2020, no. 2, 2020.

[16] J. Zhang and Y. Li, "The stability of gob-side entry retaining in a high-gas-risk mine," Advances in Civil Engineering, vol. 2019, Article ID 7540749, 2019.

[17] Z. Han, C. Wang, C. Wang, X. Zou, Y. Jiao, and S. Hu, “A proposed method for determining in-situ stress from borehole breakout based on borehole stereo-pair imaging technique," International Journal of Rock Mechanics and Mining Sciences, vol. 127, Article ID 104215, 2020.

[18] A. M. Abudeif, M. A. Mohammed, R. E. Fat-Helbary, H. M. El-Khashab, and M. M. Masoud, "Integration of 2D geoelectrical resistivity imaging and boreholes as rapid tools for geotechnical characterization of construction sites: a case study of New Akhmim city, Sohag, Egypt," Journal of African Earth Sciences, vol. 163, Article ID 103734, 2020.

[19] N. T. Smith, J. Shreeve, and O. Kuras, "Multi-sensor core logging (MSCL) and X-ray computed tomography imaging of borehole core to aid 3D geological modelling of poorly exposed unconsolidated superficial sediments underlying complex industrial sites: an example from Sellafield nuclear site, UK," Journal of Applied Geophysics, vol. 178, Article ID 104084, 2020.

[20] G. Feng and P. Wang, "Stress environment of entry driven along gob-side through numerical simulation incorporating the angle of break," International Journal of Mining Science and Technology, vol. 30, no. 2, pp. 189-196, 2020.

[21] W. Huang, X. Wang, Y. Shen, F. Feng, K. Wu, and C. Li, "Application of concrete-filled steel tubular columns in gob-side entry retaining under thick and hard roof stratum: a case study," Energy Science \& Engineering, vol. 7, no. 6, pp. 2540-2553, 2019.

[22] J. Yang, M. He, and C. Cao, "Design principles and key technologies of gob side entry retaining by roof pre-fracturing," Tunnelling and Underground Space Technology, vol. 90, pp. 309-318, 2019. 